\title{
INDIGENISMO EMPRESARIAL EM BELO MONTE: UMA ETNOGRAFIA DA POLÍTICA DO LICENCIAMENTO AMBIENTAL DE UM MEGAEMPREENDIMENTO NA AMAZÔNIA
}

Rafael Costa $ه$ 


\section{RESUMO}

Este artigo é resultado de uma etnografia baseada na minha experiência como consultor ambiental durante a construção da usina hidrelétrica de Belo Monte. Mais especificamente, da minha participação como pesquisador nos Estudos Complementares do Rio Bacajá, os quais, seguindo determinação da Fundação Nacional do Índio, objetivavam o levantamento dos aspectos ecológicos do rio Bacajá, com especial atenção aos modos de vida dos Xikrin da Terra Indígena Trincheira Bacajá, cujas aldeias estão localizadas às margens desse rio. A análise desse campo suscita oportuna reflexão sobre a prática do "indigenismo empresarial", processo que, segundo Stephen Baines, submete o ordenamento jurídico-administrativo das políticas indigenistas do Estado aos interesses privados de corporações empenhadas na instalação de empreendimentos no interior, através ou nos limites de territórios indígenas. Busco problematizar a estrutura prática do indigenismo empresarial, de forma a explorar como suas regras e princípios tecnocráticos dissimulam a temporalidade destrutiva do capitalismo.

Palavras-chave: indigenismo empresarial; etnografia; Belo Monte; Amazônia.

\section{CORPORATE INDIGENISM IN BELO MONTE: AN ETHNOGRAPHY OF THE ENVIRONMENTAL LICENSING POLICY OF A MEGA-BUSINESS IN THE AMAZON}

This article is the result of an ethnography based on my experience as an environmental consultant during the construction of Belo Monte dam. In particular, about my participation as a researcher in the Complementary Studies of the Bacajá River, which, following the determination of the Brazilian Indigenous Foundation, focused on the ecological aspects of the Bacajá river, especially the ways of life of the Xikrin population located on the banks of the river. The analysis of this field raises a timely reflection on "corporate indigenism" practice, a process that, accordingly to Stephen Baines, submits the legal and administrative order of the state's indigenist policies to the private interests of companies and corporations engaged in the installation of enterprises in, across or on the frontiers of indigenous territories. I intend to problematize the practical structure of corporate indigenism in order to explore how its rules and principles (bureaucratic and techno-scientific) disguise the destructive temporality of capitalism.

Keywords:

ethnography; Belo Monte; Amazon.

\section{INDIGENISMO EMPRESARIAL EN BELO MONTE: UNA ETNOGRAFÍA DE LA POLÍTICA DEL LICENCIAMIENTO AMBIENTAL DE UN MEGAPROYECTO EN LA AMAZONIA}

Este artículo resulta de una etnografía basada en mi experiencia como consultor ambiental durante la construcción de la hidroeléctrica de Belo Monte. Específicamente, de mi participación en los Estudios Complementares del Río Bacajá, que, siguiendo la directriz de la Fundación Nacional del Indio, objetivaban el levantamiento de los aspectos ecológicos del río Bacajá, con especial atención a los modos de vida de los Xikrin de la Tierra Indígena Trincheira Bacajá, cuyas aldeas están localizadas a márgenes de este río. Este análisis suscita una oportuna reflexión sobre la práctica del "indigenismo empresarial" que, según Stephen Baines, somete el ordenamiento jurídico-administrativo de las políticas indigenistas del Estado a los intereses privados de corporaciones empeñadas en la instalación de emprendimientos dentro, a través, o en los límites de los territorios indígenas. Busco problematizar la estructura práctica del indigenismo empresarial para explorar cómo sus reglas y principios tecnocráticos disimulan la temporalidad destructiva del capitalismo.

Palabras clave: indigenismo empresarial; etnografía; Belo Monte; Amazonia. 


\section{INTRODUÇÃO: A AUTOANTROPOLOGIA DE UMA EXPERIÊNCIA PROFISSIONAL NO CAMPO DO INDIGENISMO EMPRESARIAL}

Este artigo traz uma autoantropologia da minha experiência como consultor ambiental no processo de licenciamento ambiental da usina hidrelétrica Belo Monte $^{1}$, entre os anos de 2010 a 2013, em uma empresa privada $^{2}$.Para a presente exposição, tomo como recorte analítico a minha participação na execução de uma condicionante específica da Licença de Instalação (LI) de Belo Monte, os Estudos Complementares do Rio Bacajá (ECRB) (Norte Energia 2012a). Tais estudos, ordenados a partir de parecer técnico da Fundação Nacional do Índio (FUNAI), objetivavam o levantamento dos "aspectos de navegabilidade, ictiofauna, sedimentação [qualidade da água] e hidrologia" (FUNAI 2009:68) do rio Bacajá, com especial atenção à correlação desses aspectos com os modos de vida dos Xikrin, da Terra Indígena Trincheira Bacajá (TITB), fortemente dependentes desse rio ${ }^{3}$.

A autoanálise de tal experiência traz à tona uma oportuna reflexão sobre a prática do "indigenismo empresarial" na Amazônia, processo que, segundo o antropólogo Stephen Baines (1995, 2004, 2012), submete o ordenamento jurídico-administrativo das políticas indigenistas do Estado aos interesses privados de empresas e de corporações, empenhadas na instalação de grandes empreendimentos econômicos no interior, através e/ou nos limites de terras indígenas (como barragens para geração de energia hidrelétrica, mineração, rodovias, complexos portuários, projetos do agronegócio, entre outros) (Baines 1995, 2004, 2012).

Nesta reflexão, busco problematizar a estrutura prática do indigenismo empresarial, de forma a explorar como suas regras e seus princípios, ancorados em aparatos tecnocientíficos e burocráticos, dissimulam, ao invés de evidenciarem, a temporalidade destrutiva do capitalismo moderno. Contudo, o argumento central do artigo não trata de denunciar a forma como o aparelhamento do indigenismo empresarial "tem o efeito de diminuir os impactos desmedidamente nefastos de uma grande usina hidrelétrica" (Baines

1 Belo Monte é um empreendimento de aproveitamento hidroenergético do rio Xingu, no estado do Pará, na região Norte do Brasil. Sua construção iniciou-se em setembro de 2011, a partir da concessão da licença de instalação pelo Instituto Brasileiro de Meio Ambiente e dos Recursos Naturais Renováveis (IBAMA) e segue sendo implantada, considerando-se que nem todas as turbinas de geração de energia foram instaladas até o momento.

2 Nomeadamente, a Leme Engenharia. Originalmente, uma empresa de engenharia consultiva constituída em 1965, no estado de Minas Gerais, que, desde 2000, passou a ser subsidiária da empresa de engenharia belga Tractebel, tendo adotado seu nome desde 2013. A Tractebel, por sua vez, pertence ao Grupo Engie, que é uma empresa de capital misto da França, mundialmente reconhecida como uma das maiores produtoras de energia elétrica, com atuação em 70 países. No Brasil, a Tractebel/Engie tem uma atuação marcante no avanço da fronteira hidrelétrica do Estado brasileiro sobre a Amazônia, destacando sua participação na engenharia consultiva dos projetos das usinas de Santo Antônio e Jirau. Sua atuação na prestação de serviços ambientais no país é iniciada, pelo menos, desde 2005, a partir da coordenação dos Estudos de Impacto Ambiental (EIA) de Belo Monte (Eletrobrás 2009a).

3 Os ECRB compõem uma determinação da FUNAI (FUNAI 2009), elaborada a partir de sua análise dos Estudos do Componente Indígena (ECI) dos Estudos de Impacto Ambiental (EIA) de Belo Monte (Eletrobrás 2009a, 2009b). A recomendação da FUNAI para que os Estudos Complementares fossem realizados segue, por sua vez, determinação do Instituto Brasileiro do Meio Ambiente e dos Recursos Naturais Renováveis (IBAMA), em sua análise ambiental dos estudos do componente indígena do EIA de Belo Monte (IBAMA 2009 apud FUNAI 2009), como condição para a aprovação da licença de instalação da usina. 
2012:119), embora tal tema não esteja ausente do texto, mas sim busca demonstrar como tal mascaramento é experimentado pelos profissionais executores de tais políticas. No caso aqui analisado, os analistas ambientais de empresas privadas de consultoria ambiental. Desse modo, o objetivo principal do texto é oferecer um relato autoetnográfico deste processo de dissimulação/mascaramento vivenciado pelos praticantes do indigenismo empresarial (no caso específico, dos ECRB).

Dada a nova estruturação das políticas públicas no Brasil (Sousa Lima \& Castro 2015), onde a formulação de planos, ações e tecnologias de governo não se restringe às organizações administrativas dos Estados, mas se expandem por diferentes modalidades de organizações (Sousa Lima \& Castro 2015:35), a responsabilidade de uma empresa privada em conduzir o levantamento de informações complementares sobre os impactos de uma usina hidrelétrica contra determinado território indígena deve ser sim problematizada. Contudo, o que acontece quando a "racionalidade" ou o aparelhamento desse processo se depara com as dimensões afetivas, de dúvida, de ansiedade, de incerteza e de contenção, experimentadas pela pessoa humana alocada nesses campos, na qualidade de "indigenista empresarial"?

Nesse sentido, a partir da descrição da forma como a política do indigenismo empresarial, no caso específico dos ECRB, está estruturada de modo a dissimular a dimensão destrutiva do megaempreendimento e estabilizá-la em uma rotina tecnocientífica e burocrática. Busco problematizar as implicações dessa estrutura para os profissionais que executam tais políticas, bem como para as comunidades indígenas atingidas por essas intervenções. Com esse objetivo, uma reflexão teórica é possibilitada: explorar os níveis (possíveis) de sensitividade e de reação intuitiva dos profissionais do indigenismo empresarial, ao invés de enquadrá-los como máquinas/engrenagens dos aparelhos ideológicos do Estado.

Nessa perspectiva, a ênfase dada aqui, na possibilidade de etnografar o cotidiano dessas práticas, direciona menos atenção à forma como esse processo se estrutura a partir de "técnica[s] de produção de crença” (Sousa Lima \& Castro 2015:37), já que o aspecto que tentei privilegiar na descrição da experiência do profissional da consultoria ambiental (minha, por sinal) enfatiza mais as relações possíveis no campo de interação destes profissionais do que a determinação ideológica por meio da qual o processo de "fazer Estado" (Sousa Lima \& Castro 2015:39) se efetiva mediante à produção de subjetividades e de assujeitamentos a códigos de conduta e de moralidades sancionados via regulamentos jurídicoadministrativos governamentais.

Afinal, é a experiência de campo do profissional da consultoria ambiental que pretendo acentuar, a qual é profundamente marcada pelo contraponto material e espiritual das comunidades indígenas, bem como pela dimensão destrutiva do capitalismo, colocando incessantemente à prova o sistema formal de pensamento do indigenismo empresarial, assim como pontos de vista ou de crenças previamente estabelecidas. Se "o aparelho do nosso ser social pode ser desfeito e refeito pela viagem", tal como assinalou Merleau-Ponty (1991:129), é a possibilidade de explorar uma imaginável "experiência etnológica" (Merleau-Ponty 1991:129) dos profissionais do indigenismo empresarial que pretendo considerar a partir da autoetnografia dessa prática, de modo que os resultados desta análise possibilitem a estes profissionais um engajamento crítico tanto para as pressuposições quanto para os efeitos de suas ações. 
Aquilo que se convencionou chamar atualmente de "autoantropologia" - i.e., "a antropologia realizada no contexto social que a produziu", cujo resultado implica a devolução "à cultura ou sociedade em que se origina os construtos centrais dessa cultura" (Strathern 2015:134, 150) - nunca deixou de ser matéria da pesquisa etnológica. Afinal, conforme nos demonstrou Strathern (2015:150), “Colocar-se na posição de autor [de uma etnografia] é testemunhar o mundo através de olhos diferentes". E isso resulta, consequentemente, em uma alteração do ponto de vista sobre si mesmo e sobre o mundo: "Se o ponto de vista não tiver sua autoria revista - se não for absorvido como um processo enriquecedor cujo propósito é o autoconhecimento - pode-se considerar que ele acrescenta muito pouco" (Strathern 2015:150).

Nessa mesma linha, o antropólogo Tim Ingold (2003), certa vez, argumentou que "na antropologia estudamos nós mesmos, precisamente porque ela requer uma mudança de concepção de 'quem' somos, desde um exclusivo 'nós' Ocidental para um inclusivo 'nós' global” (Ingold 2003:xv). Ainda segundo Ingold (2003:xv):

\footnotetext{
Adotar uma atitude antropológica é largar mão de um pretenso pertencimento a uma associação seletiva de ocidentais, singularmente privilegiados nos seus olhares sobre os habitantes de "outras culturas", e reconhecer que ao lado desses outros, cuja companhia compartilhamos (ainda que temporariamente), somos todos companheiros viajantes neste mesmo mundo.
}

Explorar as possibilidades do desligamento dos privilégios (muitas vezes, frustrantes e desconcertantes) imanentes às posições de poder ocupadas pelos profissionais do indigenismo empresarial, possibilidades estas ativadas a partir do contraponto indígena, é o objetivo principal deste artigo. Dessa forma, antevê-se a possibilidade de desconectar a atividade cognitiva dos profissionais da consultoria ambiental em relação aos constrangimentos ${ }^{4}$ que condicionam a sua atuação política à lógica operacional do setor elétrico (cf. Zhouri \& Oliveira 2013) e reativá-la às perplexidades que seus sistemas de regras, procedimentos operativos e códigos de condutas morais tentam dissimular, mas cuja "lógica" os indígenas não deixam de asseverar.

\section{O CONTRAPONTO INDÍGENA: "KUBẼN DO NGÔ BEYÊT, O RIO BACAJÁ VAI SECAR"}

Eu sei que o rio Bacajá vai secar, todos os Xikrin sabem, mas vocês não querem acreditar. Eu vou falar reto para você, falar direto, porque Mebêngôkre fala assim forte e reto, não enrola ninguém. Quero apostar com você. Se vocês estiverem certos e o rio Bacajá não secar com o barramento do Xingu, vocês voltarão aqui na aldeia e poderão me amarrar num pau no meio da aldeia onde eu ficarei amarrado três dias e três noites, sem comer e nem beber água. Agora, se vocês estiverem errados e o rio Bacajá secar, ficar quente e rápido eu vou te buscar e vou te amarrar aqui na aldeia por três dias e três noites, sem água e sem comida. Vocês precisam aprender que os Xikrin conhecem o rio Bacajá e sabem que ele vai secar se o rio Xingu for barrado. Os Xikrin falam certo e vocês falam feio, falam mentira (Meiti Xikrin, TITB, abr. 2012, registro e tradução feitos por Mantovanelli 2016a:197).

4 Ou, como diria Bourdieu (2003:284), das "propriedades tristemente impessoais". 
O rio Bacajá é o principal tributário do rio Xingu, na região da Volta Grande ${ }^{5}$. Boa parte da sua bacia hidrográfica (com área aproximada de 1.650 .000 hectares) é ocupada pela Terra Indígena Trincheira Bacajá (TITB) (cerca de 1.500 .000 hectares) (Figura 1), que, por sua vez, é habitada pelos Xikrin, um dos ramos dos Kayapó Setentrionais, falantes da língua Mebêngôkre, pertencentes à família Jê. A TITB é uma grande aliada na preservação ambiental da bacia hidrográfica do rio Bacajá, uma vez que seus limites territoriais ajudam a conter o desmatamento da floresta amazônica, iniciado pelo processo de assentamento rural nas margens da rodovia Transamazônica a partir da década de 70 (Anexo 1).

Minha atuação nos Estudos Complementares do Rio Bacajá (ECRB), ordenados a partir de parecer técnico da FUNAI (2009) no processo de licenciamento ambiental de Belo Monte (já mencionado), concentrou-se no registro dos aspectos socioeconômicos da navegação que os Xikrin empreendiam no rio Bacajá e entre a TITB e a cidade de Altamira, a fim de fundamentar eventuais medidas mitigatórias e compensatórias para manutenção das condições de navegabilidade e acessibilidade dos Xikrin, em decorrência das mudanças nos regimes hidrológicos dos rios Xingu e Bacajá a partir da instalação de Belo Monte.

Para tanto, visitei a Terra Indígena três vezes durante todo o ano de 2012, em datas espaçadas, de modo a cobrir a navegação praticada pelos Xikrin nos respectivos ciclos hidrológicos dos rios Bacajá eXingu, de seca, cheia e vazante/enchente, respectivamente. Foram mais de $2.500 \mathrm{~km}$ percorridos pelos rios Xingu e Bacajá ao longo daquele ano, contabilizando tanto o trajeto entre a cidade de Altamira até as cinco aldeias da TITB $^{6}$ quanto os deslocamentos no interior do território Xikrin, para mapeamento da navegação local. A viagem realizada no período de seca foi a mais demorada, com duração de cinco dias, tempo necessário para completar os $700 \mathrm{~km}$ de ida e volta, desde a cidade de Altamira até a aldeia mais a montante no rio Bacajá, Mrotidjãm, naquela época do ano.

As outras equipes dos estudos, responsáveis pelo levantamento da ictiofauna e da qualidade da água, também realizaram campanhas de campo na TITB ao longo dos ciclos hidrológicos do rio Bacajá. A ideia era caracterizar os aspectos da biota aquática e da qualidade da água daquele rio em cada um de seus períodos hidrológicos, tal como se previu para a caracterização da navegação, de modo a correlacionar os resultados desse diagnóstico com a reprodução dos modos de vida Xikrin (e.g., consumo proteico, saúde humana, disponibilidade de recursos, mobilidade, escoamento da produção e etnoecologia).

Contudo, a questão central em torno da qual se estruturava os ECRB concentrava-se nos efeitos do

\footnotetext{
5 Denominação atribuída ao trecho fluvial do rio Xingu, com extensão de aproximadamente cento e quarenta quilômetros, localizado entre a cidade de Altamira, no Pará, e a comunidade de pescadores Belo Monte do Pontal, no distrito do município de Vitória do Xingu, também no Pará. O trecho é assim denominado em razão da acentuada curva que o rio traça na sua área de transição entre o médio e o baixo Xingu.

6 Em 2012, eram cinco as aldeias dos Xikrin na TITB: Pykayakà, mais próxima à foz do rio Bacajá, no rio Xingu, a aproximadamente $60 \mathrm{~km}$ da foz; Pot-Krô, a aproximadamente $100 \mathrm{~km}$ da foz; Pytako (ou aldeia do Onça), localizada a $160 \mathrm{~km}$ da foz; além das aldeias Bacajá e a Mrotidjãm, localizadas na região mais a montante da TI, a aproximadamente 270 km da foz. Recentemente, nove aldeias compõem a TITB. Além das já citadas, fazem parte, ainda, Khãnh, Kamôktkô, Kenkudjoi e Rapkô.
} 


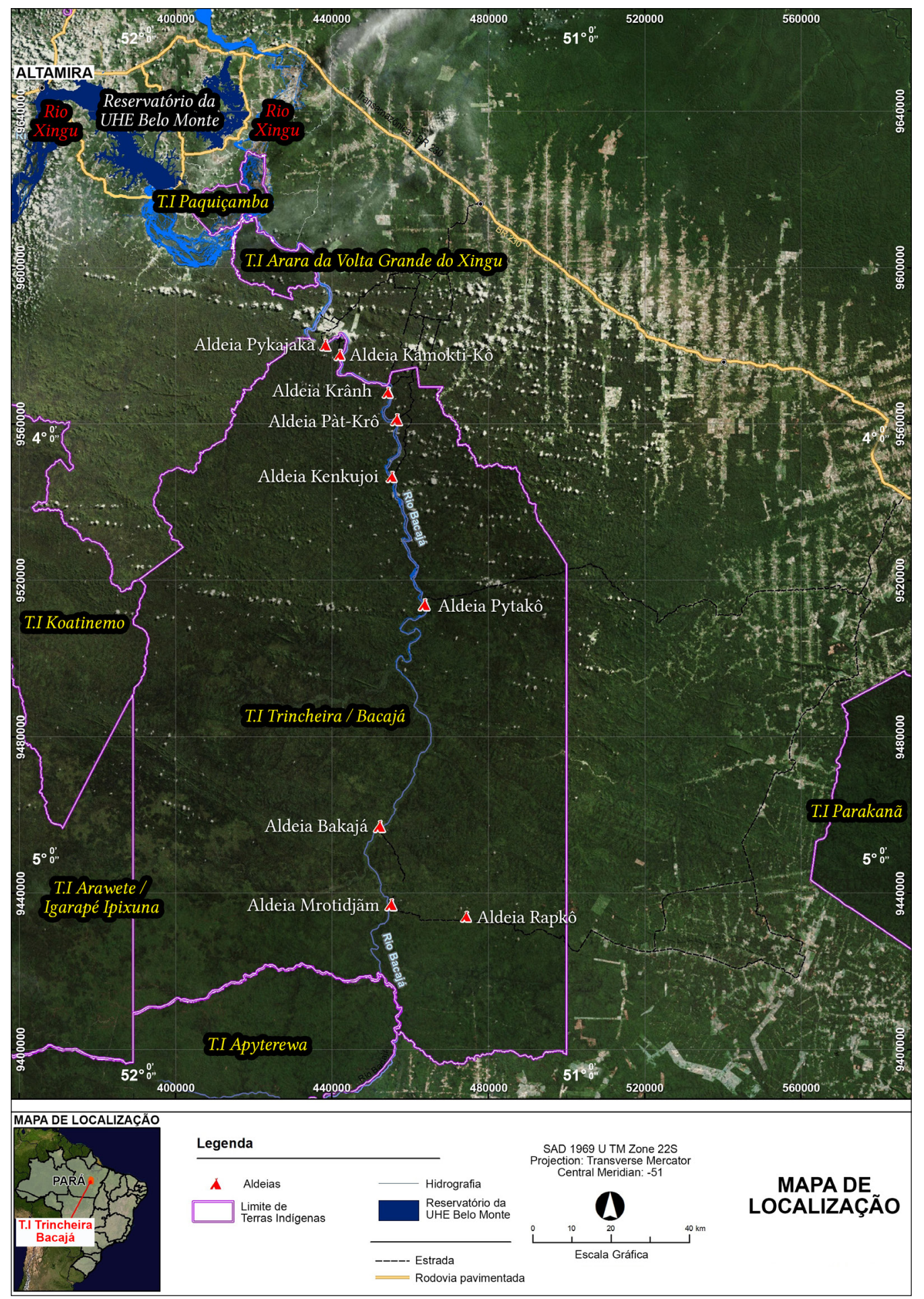

Figura 1 - Mapa de localização da TITB e de suas aldeias em relação à usina Belo Monte. Fonte: Norte Energia (2009a). 
barramento do rio Xingu sobre este rio. Conforme apontado pelos Estudos de Impacto Ambiental (EIA) da usina Belo Monte (Eletrobrás 2009a:40-42), o baixo curso do rio Bacajá seria afetado pela imposição da vazão reduzida na Volta Grande do Xingu, devido à diminuição do "efeito de remanso" neste trecho, pois, no baixo curso do rio Bacajá, em uma condição sem a usina (i.e., natural), o rio Xingu avançava sobre sua foz por uma extensão de, aproximadamente, $25 \mathrm{~km}$ no seu ciclo de cheia, gerando efeito de represamento do rio Bacajá neste período. Esta característica é que é denominada pelos engenheiros hídricos dos ECRB como "efeito de remanso"?

Conforme apontado no EIA (Eletrobrás 2009a), com o início da operação de Belo Monte e a imposição da vazão reduzida na Volta Grande ${ }^{8}$, as cheias do rio Xingu iriam "diminuir drasticamente, comprometendo o curso do baixo Bacajá... pois o rio Bacajá depende das cheias anuais do rio Xingu para a reprodução de seus processos ecológicos" (Eletrobrás 2009a: 41-42). Desse modo, após a instalação da usina, a inundação das planícies aluviais e do canal do baixo curso do rio Bacajá nos ciclos de cheia do rio Xingu não seriam mais registradas.

Entre os danos prognosticados pelo EIA(Eletrobrás 2009a), a partir da alteração nos regimes hidrológicos dos rios Xingu e Bacajá, poder-se-iam destacar: i) comprometimento dos fluxos de peixes migratórios e de seus processos reprodutivos e, consequentemente, a diversidade de espécies da ictiofauna encontrada no interior da TITB; ii) aumento da velocidade do escoamento fluvial do rio Bacajá, sem o "efeito remanso" do rio Xingu, o que comprometeria a estabilidade de suas encostas; iii) a exposição do baixo curso do Bacajá a uma condição contínua de seca comprometeria a navegação no local, uma vez sendo identificada ali a formação de fortes corredeiras durante os ciclos hidrológicos de seca. Ainda segundo o EIA(Eletrobrás 2009a), o trecho fluvial do baixo curso do rio Bacajá era um dos locais de maior biodiversidade relativa na "área de abrangência" definida para os estudos de impacto ambiental de Belo Monte.

7 Segundo os engenheiros hídricos responsáveis pelos estudos hidrológicos dos ECRB: "Por efeito de remanso, entendese a desaceleração das águas de um curso de água devido a alguma restrição física ao escoamento. A foz do rio Bacajá no rio Xingu tem seu escoamento sujeito ao remanso das águas provocado pela maior magnitude das vazões do rio Xingu quando comparadas às do rio Bacajá [no ciclo hidrológico de cheia]” (Norte Energia 2012a:10).

8 Com o barramento do rio Xingu e o desvio de suas águas para conformação de um segundo reservatório (onde estão sendo instaladas as turbinas da Casa de Força Principal da usina), uma extensão de aproximadamente cem quilômetros do trecho fluvial da Volta Grande, a jusante do eixo do barramento principal da hidrelétrica, será submetida a uma vazão residual. Essa imposição foi reconhecida pelos estudos ambientais da usina, muito contraditoriamente, como "hidrograma ecológico de consenso" ou "hidrograma mínimo" (Norte Energia 2011:367). Afinal, a definição das vazões mínimas para o trecho, de modo a, supostamente, permitir a manutenção da "sazonalidade do regime fluvial da região, sem, contudo, prejudicar significativamente o desempenho da usina quanto à sua capacidade de produção" de energia (Eletrobrás 2009a:206), foi uma definição meramente técnica, tomada de forma monocrática pelos profissionais que coordenaram e executaram o EIA da usina, sem o consentimento das populações locais da Volta Grande - como os próprios técnicos afirmam em artigo publicado no XX Seminário Nacional de Produção e Transmissão de Energia Elétrica. Segundo eles: "O EIA chegou à conclusão de que se deve garantir vazões mínimas que permitam a navegação no período de seca e vazões de cheias que permitam pelo menos um mínimo de inundação das florestas aluviais, além da manutenção da variação dessas vazões, mesmo que em menos amplitude, de forma semelhante ao que ocorre hoje" (Garcia et al. 2009:7). 
A partir desse cenário, o impacto direto da alteração hídrica e territorial dos rios Xingu e Bacajá provocada pela usina sobre as condições de vida dos Xikrin deveria ser melhor estudado,

\begin{abstract}
a fim de esclarecer dúvidas sobre as possibilidades de assoreamento [do rio Bacajá], diminuição de vazão, impactos sobre ictiofauna, que pode[ria]m comprometer de alguma maneira tanto as atividades de subsistência (pesca) como comerciais (castanha) e a locomoção das comunidades Xikrin (IBAMA apud FUNAI 2009:5 grifo meu).
\end{abstract}

Realizadas as campanhas, os resultados finais dos Estudos Complementares do Rio Bacajá corroboraram as dimensões destrutivas da usina previstas no EIA e em pareceres técnicos da FUNAI e do IBAMA, além de projetarem as medidas a serem adotadas para mitigar e compensar os impactos prognosticados. Contudo, o "esclarecimento das dúvidas" com relação aos efeitos desse diagnóstico sobre os modos de vida dos Xikrin da TITB não pôde ser sanado pelas alternativas propostas pelos analistas ambientais responsáveis pelos ECRB. E foi exatamente contra essa situação de incerteza, esforçadamente sustentada pela prática da consultoria ambiental, que emergiu o contraponto indígena. Vejamos.

Após a conclusão das pesquisas de campo dos ECRB, do tratamento dos dados e da sistematização de seus resultados, uma série de reuniões para a apresentação dos estudos foi agendada em cada uma das aldeias da TITB. Nesses encontros, era esperado que todos os técnicos das áreas estudadas (hidrologia, ictiologia, etnoecologia, navegação e qualidade da água) estivessem presentes nas aldeias, para expor os resultados finais de suas pesquisas, de modo a informar os Xikrin sobre as ações em curso e que ainda seriam implementadas, a fim de conter o prognóstico destrutivo anunciado. Em outras palavras, isso foi feito para reduzir a "preocupação dos Xikrin" (como enunciava um dos materiais gráficos utilizados nas reuniões) com relação à reprodução de seus modos de vida após a instalação de Belo Monte.

Contudo, apesar da reunião cumprir o protocolo procedimental previsto pelos ECRB, no contexto do licenciamento ambiental do empreendimento hidrelétrico, sua eficácia em informar e, assim, sanar a inquietação dos indígenas com relação ao futuro do rio Bacajá, a partir da construção da usina, não foi alcançada. Afinal, mesmo reunidos nas aldeias com todo seu conhecimento acumulado, equipados com imagens, gráficos, mapas e cartazes coloridos (banners) - que detalhavam os métodos empregados nas pesquisas, os equipamentos técnicos utilizados e todo o esforço de campo empreendido pelos pesquisadores para chegarem aos seus resultados, contando, inclusive, com a participação e envolvimento direto dos Xikrin -, os analistas ambientais não foram capazes de contradizer o argumento dos indígenas de que "o rio Bacajá iria secar" ou convencê-los do contrário.

Foram muitos os dados apresentados pelos profissionais dos ECRB durante as reuniões, mas as discussões findavam-se sempre na oposição, de um lado, dos Xikrin, afirmando que "o rio Bacajá iria secar", e, de outro, dos analistas ambientais do ECRB, afirmando que não, "o rio Bacajá não iria secar". Antes de adentrarmos nas justificativas apresentadas por cada um dos lados desse desacordo, é válida a exposição daquilo que estava sendo apresentado e proposto pelos analistas 
ambientais durante as reuniões, nas aldeias da TITB. Trata-se de uma exposição que nos ajuda a reconhecer um dos motivos dessa divergência.

Por exemplo, no que se refere aos levantamentos da ictiofauna - os quais buscaram conhecer a biodiversidade das espécies de peixes do rio Bacajá (sua riqueza, raridade, endemismo e abundância), suas dinâmicas ecológicas (ambientes preferenciais, migração e biologia reprodutiva), bem como sua importância para a manutenção de aspectos socioeconômicos dos Xikrin (pesca, consumo e comercialização) -, foi apresentado que a foz deste rio é um local "muito importante" para a reprodução no que tange a este aspecto, e que, devido à diminuição das áreas de inundação neste local a partir da instalação da usina (um dos ambientes preferenciais para a reprodução das espécies da ictiofauna do rio Bacajá), "espera-se uma redução da abundância da ictiofauna nessa região" (Norte Energia 2012b:6).

Ademais, foi também apresentado pelas equipes dos estudos sobre a ictiofauna que a diminuição das áreas de inundação na foz do rio Bacajá iria dificultar a subida de algumas espécies de peixes migradores até a TITB, principalmente os de maior porte, como o surubim e o pirarara, o que acarretaria também redução da biodiversidade da ictiofauna no interior da TITB e, consequentemente, comprometimento das dinâmicas socioeconômicas dos Xikrin, considerando-se que tais espécies eram consumidas e comercializadas pelos indígenas durante os ciclos hidrológicos de vazante e seca do rio (Norte Energia 2012b).

Contudo, surpreendentemente, mesmo após tal previsão já ter sido apresentada no EIA, nos pareceres da FUNAI e do IBAMA e, agora, nos ECRB, era afirmado que

\begin{abstract}
A real magnitude dos impactos no recrutamento, alimentação e migrações da ictiofauna pelas alterações do rio Bacajá só poderia ser medida com projetos de monitoramento, já que não existem para a região informações mais precisas que permitam dimensionar exatamente a intensidade do decréscimo da biomassa de peixes nessas novas condições (Norte Energia 2012b:7, grifo meu).
\end{abstract}

Com esse argumento, os analistas ambientais, especialistas em ictiofauna, afirmavam, durante as reuniões nas aldeias Xikrin, que um monitoramento seria necessário para saber 'ao certo' se a redução do "efeito de remanso" do Xingu sobre o Bacajá comprometeria a pesca, a reprodução e a migração das espécies de peixes encontradas no rio Bacajá. Nesse sentido, sustentavam que as características da biodiversidade e da ecologia da ictiofauna deste rio deveriam ser revistas regularmente nos próximos anos, durante e após a construção da usina, por estudos de monitoramento específicos e em locais definidos ao longo dele.

Essa mesma proposta de "monitoramento" foi reproduzida pelos pesquisadores de outras especialidades dos ECRB. Por exemplo, no caso dos estudos etnoecológicos, os quais objetivavam compreender como os ambientes da TITB eram utilizados pelos Xikrin nas diferentes épocas do ano, tendo apontado a relevância da alimentação indígena baseada na caça e na pesca ${ }^{9}$, medidas de monitoramento também foram propostas. Entre

9 Segundo os resultados dos estudos sobre o consumo de fontes proteicas de alimentos, realizados nas aldeias da 
elas, destaque-se a fiscalização e a recuperação das fronteiras e do entorno da TITB, ameaçadas pelo avanço de atividades ilegais de extração de madeira, garimpo, criação de gado, caça e pesca. Este é um cenário que poderia ser intensificado pela maior disponibilidade de acesso via terrestre à TITB, uma das medidas compensatórias propostas para garantir a acessibilidade dos Xikrin.

$\mathrm{Na}$ realidade, todas os especialistas dos ECRB propuseram essa dinâmica de monitoramento. Em relação à qualidade da água, por exemplo, uma vez identificado que o rio Bacajá possui água de boa qualidade para a manutenção da fauna e flora local, não sendo contaminado por substâncias químicas, como pesticidas, óleos e graxas, também foi proposto pelos analistas o monitoramento desse aspecto em relação ao rio Bacajá durante e após a construção da usina. Da mesma forma, medidas de monitoramento foram propostas pelas equipes dos estudos sobre a navegação, a principal forma de acesso dos Xikrin à TITB em 2012. Em diálogo constante com a equipe de hidrologia, foi constatada que a redução do "efeito remanso" do Xingu sobre o Bacajá dificultaria a transposição fluvial de embarcações nas corredeiras que se formavam durante a seca nos quilômetros iniciais deste rio desde a sua foz. Assim, medidas de monitoramento da navegação foram também previstas.

Ou seja, todas as exposições dos analistas ambientais aos Xikrin sobre os resultados dos ECRB e, de modo consequente, os encaminhamentos propostos para a manutenção dos aspectos ecológicos relacionados aos rios Xingu e Bacajá, assim como à reprodução dos modos de vida Xikrin, tiveram em comum a apresentação de uma proposta de monitoramento dos efeitos do empreendimento sobre a hidrologia, a ictiologia, a etnoecologia, a qualidade da água e a navegabilidade do rio Bacajá. Isto é, dito de um modo mais sincero, todas as exposições realizadas pelos especialistas dos ECRB nas aldeias Xikrin tiveram em comum a tentativa de estabilizar a dimensão destrutiva de Belo Monte sobre a vida na TITB em uma rotina prática, materializada por meio da política tecnocientífica e burocrática do licenciamento ambiental.

Como afirmou Andrew Goffey (2011), na introdução de sua tradução da obra "Capitalism sorcery”, de Philippe Pignarre \& Isabelle Stengers (2011), "o tipo de destruição que ocorre sob a égide do progresso ou da modernidade depende da criação de um ambiente de práticas rotineiras e estabilizadas" (Goffey 2011:xiv). E a forma como a estabilização dessa dimensão destrutiva é conduzida pelos agentes do capitalismo deve ser explorada, sobretudo quando tais sujeitos são incapazes de hesitar "na presença dos fatos contínuos de destruição" (Stengers 2005:186) que a sua prática representa (embora essa competência não esteja afastada de certas doses de pânico e desespero que, por ventura, esses profissionais experimentem).

TITB, no âmbito dos ECRB, "As taxas de consumo de alimentos proteicos denotam índices altos; os valores vão de 401 g.capita ${ }^{-1}$.dia ${ }^{-1}$, na cheia, a 589 g.capita ${ }^{-1} \cdot$ dia $^{-1}$, na vazante, que correspondem a aproximadamente 90 g de proteínas por pessoa, quase três vezes mais do que o mínimo recomendado pela Organização Mundial da Saúde, que é de $36 \mathrm{~g}$ para uma pessoa de $60 \mathrm{~kg}$ de peso. O peixe está em primeiro lugar, com médias de $232 \mathrm{~g}$. capita $^{-1}$.dia ${ }^{-1}[\ldots]$. Em segundo lugar está a carne de caça, com 146 g.capita ${ }^{-1} \cdot$ dia $^{-1}$. Estes resultados denotam a importância da conservação dos recursos naturais para a segurança alimentar das comunidades" (Norte Energia 2012b:7). 
É certo que o trabalho de estabilização das dimensões destrutivas de Belo Monte na rotina prática do monitoramento ambiental relativo ao licenciamento da usina está associado à "fabricação, laboriosa, de uma multitude de atores que, juntos, fazem conexões, equipamentos e operações que a asseguram, mantêm e suportam" (cf. Pignarre \& Stengers 2011:28 apud Latour 2000). Como afirmou Latour (2000:50, grifo do autor), "o status de uma afirmação depende das afirmações ulteriores”. Todo trabalho de construção da certeza de uma afirmação está muito mais ligado à consolidação de condições que possibilitem assegurar essas afirmações do que à afirmação em si mesma. "O rio Bacajá não vai secar", afirmam os consultores ambientais, que podem declarar, por exemplo: "para confirmar esse fato, seguiremos monitorando, o que envolverá muitos recursos, vários especialistas, bem como a validação do estado por parte das equipes do IBAMA e da FUNAI".

No entanto, o laborioso dessa relação depende também de um esforço tremendo por parte dos analistas ambientais dos megaempreendimentos para excluir e/ou conter uma série de fugas, situações, eventos, disputas e sentidos que se colocam fora dos cálculos e das intenções expressas nos aparatos tecnocráticos produzidos por estes profissionais. Afinal, na estabilização do prognóstico destrutivo previsto para a TITB (anunciado desde a elaboração do EIA de Belo Monte, em 2009) em um processo de monitoramento ambiental, o que se pretende realizar é o desvio de questões fundamentalmente perplexas e irresolutas, envoltas na construção de um megaempreendimento na Amazônia.

Logo, tudo o que parecia duvidoso com relação à viabilidade ambiental do megaempreendimento pôde, agora, ser estabilizado, a partir da linguagem normativa da rotina burocrática do monitoramento ambiental. E assim ocorreu, pelo menos em teoria. As equipes do ECRB partiram rumo à TITB com esse ideal: adquirir o consentimento dos Xikrin a respeito dos aspectos destrutivos de Belo Monte, por meio de sua autorização quanto aos procedimentos laboriosos da política do licenciamento ambiental e do indigenismo empresarial. Contudo, uma posição dos indígenas abalara essa pressuposição: "o rio Bacajá vai secar". De que servia o monitoramento ambiental proposto pelos analistas, se não haverá mais água onde pescar, navegar, banhar? Enfim, se "o rio Bacajá vai secar"?

$\mathrm{E}$, aqui, podemos retornar à discussão sobre as justificativas apresentadas por cada um dos lados desse desacordo durante as reuniões de apresentação dos resultados dos ECRB nas aldeias da TITB, em que a mobilização do conhecimento da (e pelas equipes de) hidrologia, com todo seu trabalho interpretativo já encaminhado, buscou dominar o debate, com a complacência de outros especialistas e analistas ambientais presentes. Nesse momento, a hidrologia não apenas se sobrepôs a outras disciplinas, ela foi convocada como o construto científico mais promissivo para livrar os pesquisadores dos ECRB da desconfiança, da dúvida e do protesto dos Xikrin contra a falta de sentido que representava as propostas de monitoramento ambiental do rio Bacajá. A Figura 2 traz uma expressão da reação dos Xikrin com relação às propostas dos analistas ambientais.

Contra a afirmação dos Xikrin, de que "o rio Bacajá vai secar", os engenheiros hídricos dos ECRB apontavam para a seguinte conclusão (Norte Energia 2012a:74): 


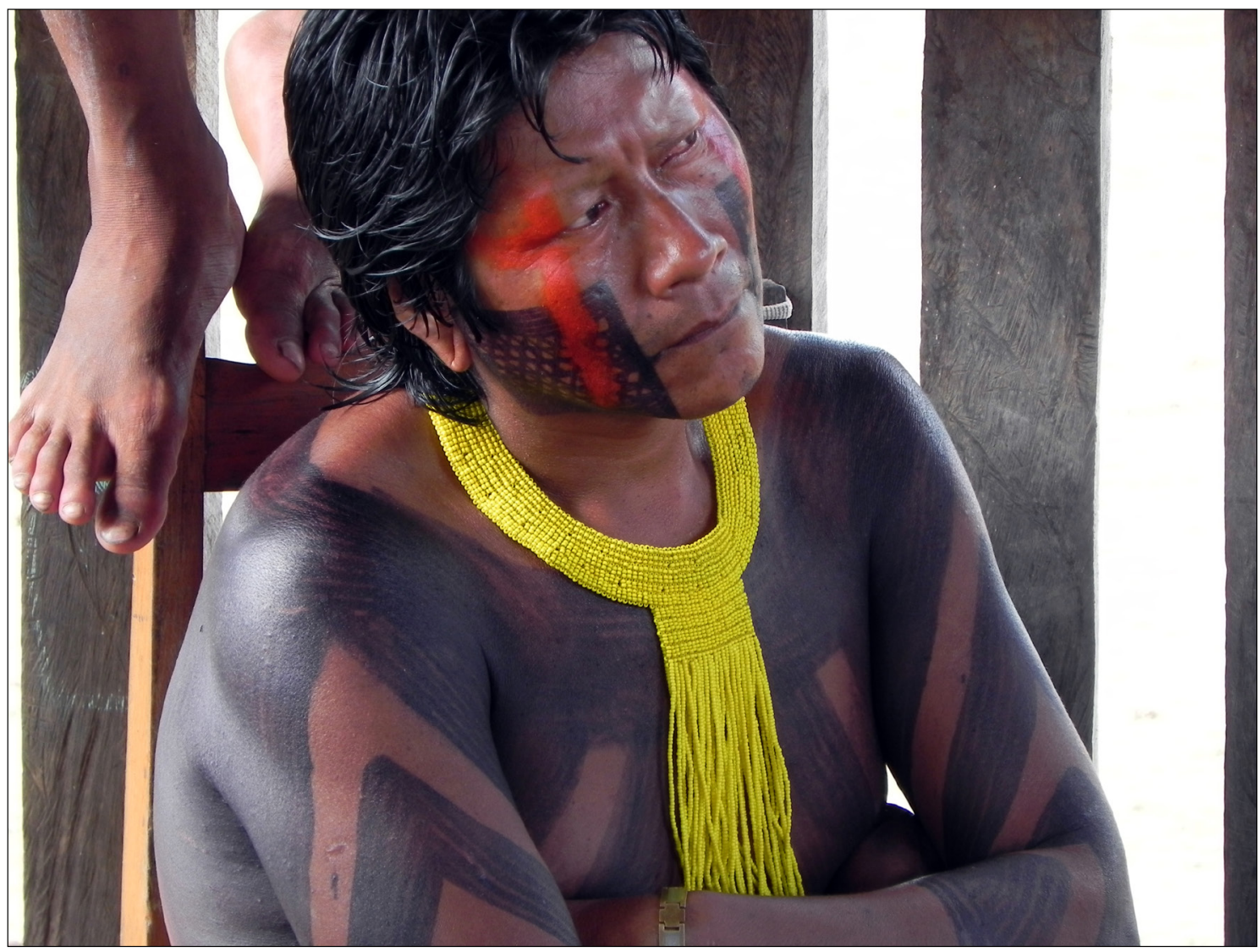

Figura 2 - Reação de um Xikrin da aldeia Pykaiakã, da TITB, durante reunião de apresentação dos resultados dos ECRB, em abril de 2012. Foto: Rafael Costa (2012).

O maior impacto simulado (diferença entre a condição natural e a condição com usina) mostra que a perda de efeito de remanso chega até... cerca de 28 km da foz do rio Bacajá, ou seja, não se espera impacto sobre o rio Bacajá dentro da Terra Indígena Trincheira Bacajá, que está a cerca de $50 \mathrm{~km}$ da foz do rio.

Nesses termos, o impacto da alteração do regime fluvial do rio Xingu a partir da instalação de Belo Monte sobre o Bacajá, segundo os resultados dos estudos hidrológicos dos ECRB, não acarretaria em "alterações significativas" nos regimes fluviais deste rio, bem como nas condições de vida das populações da TITB. E, pois, era esperado que os "ciclos de cheia, seca, vazante e enchente deste rio [no interior da TITB] permanecessem muito próximos do que ocorre hoje sem a barragem", uma vez que a mudança no regime hidrológico do rio Bacajá se restringiria aos $28 \mathrm{~km}$ iniciais desde a sua foz, conforme afirmado por um dos consultores ambientais do ECRB, durante apresentação dos resultados dos estudos aos Xikrin, fala oportunamente registrada pela antropóloga Thais Mantovanelli (2016a:195): 
A vida de vocês, Xikrin, aqui na Terra Indígena não será alterada significativamente com a construção do empreendimento porque os regimes de cheia, seca, vazante e enchente do rio Bacajá permanecerão muito próximos do que ocorre hoje sem a barragem.

Em contraposição a essa afirmativa, edificavase o posicionamento dos Xikrin. Segundo os indígenas, aquela afirmação tratava-se de algo punúre, termo classificatório mebêngôkre para designar coisas ou atitudes obscuras, incorretas, erradas, não verdadeiras (Mantovanelli 2016a, 2016b). Tais explicações desconsideravam as teorias Xikrin acerca dos impactos que a obra acarretaria ao rio Bacajá e a todo seu território, por conta do barramento do rio Xingu (Mantovanelli 2016a), uma vez que, segundo os Xikrin, o rio iria secar: "Eu sei que o rio Bacajá vai secar, todos os Xikrin sabem, mas vocês não querem acreditar", afirmara Meiti Xikrin, cacique antigo da aldeia Pot-krô, a quarta da TITB, subindo o rio desde o Xingu - fala assinalada na epígrafe desta sessão, registrada por Mantovanelli (2016a:197) durante reunião de apresentação dos resultados dos ECRB nas aldeias da TITB.

Uma das explicações que os Xikrin ofereciam para justificar o seu argumento (cf. Mantovanelli 2016b) alertava para uma variação brusca da hidrologia dos rios Xingu e Bacajá a cada dez anos, aproximadamente:

\begin{abstract}
Segundo os Xikrin, a cada período de dez anos (aproximadamente) os rios Bacajá e Xingu vivenciam uma seca bastante severa e mais duradoura. Por esse motivo, afirmavam que um ano de realização de estudos não era suficiente para que os engenheiros entendessem e vissem esse período de seca (Mantovanelli 2016b:182).
\end{abstract}

Do outro lado, os consultores ambientais (os kubẽn do ngô beyêt, tal como os Xikrin os denominaram ${ }^{10}$ ), a partir do conhecimento produzido pelos profissionais da engenharia hídrica dos ECRB, afirmavam que se tratava de uma questão de "modelagem matemática", cujos resultados - obtidos a partir da projeção justaposta dos dados das séries históricas das vazões do rio Bacajá entre os anos 1977 a 2011, com a disponibilidade de dados topobatmétricos deste rio e de informações quanto à vazão do rio Xingu ${ }^{11}$ -

10 Kkubẽn do ngô beyêt é como os Xikrin denominam os brancos da usina Belo Monte, na tradução literal: "brancos da água barrada”. Uma expressão formada pelas palavras Mẽbengôkre Kubẽn (brancos) e ngô beyêt (denominação atribuída à barragem de Belo Monte enquanto "água barrada”, "água pobre, água velha, água suja”) e pela conjunção de pertença "do" em português (cf. Mantovanelli 2016a:20, 24; 2016b:160).

11 Para o cálculo da modelagem matemática, os valores do histórico das vazões do rio Xingu e os das vazões reduzidas previstas para a Volta Grande do Xingu após a instalação da usina foram transformados em cotas na região da foz do rio Bacajá, cujo resultado permitiu simular não apenas o avanço "natural” das águas do Xingu sobre o rio Bacajá nos períodos de cheia sob uma condição sem a usina, mas também a simulação de como seria esse avanço e quais as condições do rio Bacajá após a instalação do empreendimento (Figuras 3 e 4). Os resultados das séries históricas das vazões dos rios Xingu e Bacajá são auferidos a partir de distintos cenários de simulação da linha d'água destes rios, correspondentes a: i) vazões médias do histórico de dados dos rios Xingu e Bacajá; ii) ano mais seco do histórico de 
permitiam assegurar que os efeitos do barramento de Belo Monte sobre o rio Bacajá não ultrapassariam os $28 \mathrm{~km}$ estipulados desde a sua foz, atestando, por fim, que o rio não iria secar.

Apesar desse desacordo, é válido notar que ambas as explicações - de um lado, a dos Xikrin, de que "o rio Bacajá vai secar", de outro, a dos consultores ambientais, de que "não, o rio Bacajá não irá secar" - não se tratam de abstrações ou de visões pré-concebidas da realidade, mas se sustentam a partir dos dados de sua observação, pois as duas exposições correspondem "a uma atenção mais firme em relação às propriedades do real", para utilizamos uma expressão de Lévi-Strauss (2016:17).

Contudo, como já apontara Lévi-Strauss (2016), a existência de propriedades comuns entre o pensamento indígena e o da ciência moderna - ambos sustentados pelo cuidado com a observação exaustiva dos objetos no mundo e com o ordenamento de suas relações e ligações em um plano classificatório - pode resultar em construtos sociais estranhos ou dessemelhantes, como os expressos nas distintas posições dos Xikrin e dos consultores com relação ao futuro do rio Bacajá. E a razão para tal divergência não deve ser encontrada na distinção entre métodos ou operações de pensamento, mas nas diferentes funções e em níveis estratégicos em que a natureza se deixa abordar por cada uma dessas modalidades de conhecimento (Lévi-Strauss 2016).

Ora, se em ambas as posições sobre o futuro do rio Bacajá - tanto a dos Xikrin quanto a dos analistas ambientais - as propriedades hidrológicas deste rio foram consideradas - de um lado, "as secas severas e mais duradoras dos rios Xingu e Bacajá a cada período de dez anos, aproximadamente", de outro, "os resultados das séries históricas das vazões dos rios Xingu e Bacajá e de dados topobatmétricos" -, é o modo correspondente com que cada grupo estabelece suas "relações reais" com esses objetos (i.e. com os rios Xingu e Bacajá), com base em planos perspectivos e escalas espaçotemporais bastante específicos, que permitiria a sua comparação.

Portanto, ao passo que os analistas ambientais subordinam a sua relação com o rio Bacajá à execução do projeto de aproveitamento hidrelétrico do rio Xingu, produzindo, assim, um universo de utensílios que são por eles compreendidos e procurados no curso e na execução desse projeto, do outro lado, na posição dos Xikrin, não existe esse tipo de subordinação. A relação dos Xikrin com o rio Bacajá não está definida pela transigência, complacência ou resignação ao projeto de aproveitamento hídrico do rio Xingu. Pelo contrário, sua relação com este rio não exige a subordinação a nenhum projeto em particular. Ela "constitui uma verdadeira experiência sobre o objeto" (para utilizarmos uma expressão de Lévi-Strauss 2016:41), ao mesmo tempo concreta e virtual. Não há a necessidade de reorganizá-la a partir de uma estrutura estabelecida desde outro lugar, como o fazem os analistas ambientais.

Os analistas ambientais reorganizam a sua experiência no mundo (sua experiência na Volta Grande do rio Xingu, por exemplo) a partir dos meios e do poder ilimitados que lhes são concedidos pela prática das políticas do licenciamento ambiental e do indigenismo empresarial, relativas aos megaempreendimentos do capitalismo

vazões; e iii) cenário com o ano de vazões mais altas do histórico de dados (Norte Energia 2012a). 
moderno; ao passo que os indígenas se situam aquém desses poderes, o que lhes possibilita pensar a sua relação com o rio de um modo mais próximo da intuição sensível. Aos analistas ambientais, resta pensar de modo mais distanciado dessa intuição.

Esse distanciamento tem efeitos produtivos no trabalho de estabilização da dimensão destrutiva e da incerteza provocadas por megaempreendimentos do capitalismo moderno. Afinal, essa é a condição possível para o trabalho de análise ambiental de consultorias privadas nessas situações, pois as relações reais estabelecidas por essa prática nunca estão situadas no campo propriamente traumático, incerto, duvidoso - e por isso também violento das experiências de campo das pessoas atingidas por tais empreendimentos, mas são determinadas por outros contextos, que não aqueles vivenciados no chão das megaobras do capitalismo moderno, tais como os produzidos pelas conexões entre as atividades de monitoramento e os ambientes dos laboratórios, das universidades, dos escritórios das empresas de consultoria ambiental, ou pelos processos de prestação de contas e de interlocução com órgãos ambientais, auditores externos ou com os empreendedores, propriamente.

Ao efetivar esse distanciamento, ao transigir um contexto de relações sociais sobre o outro, os analistas ambientais parecem se abster da violência e do trauma provocados pelos megaempreendimentos. Contudo, o trabalho de manutenção desse distanciamento não acontece sem percalços, pois exige uma dedicação extraordinária por parte desses profissionais, não apenas em reorganizar, continuamente, os processos políticos que sustentam tais empreendimentos (como o movimento que se estende, interminavelmente, desde a realização de estudos de impacto ambiental até a prática do monitoramento ambiental), mas, especialmente, em conter tudo aquilo que se coloca fora da lógica dos processos infindáveis dessa legitimação. Nesse movimento, há sempre uma fuga que deve ser bloqueada, algo que vaza e que deve ser contido. As definições tecnocráticas e normativas que guiam a prática da análise ambiental dos megaempreendimentos funcionam sempre de modo a conter qualquer possibilidade que ameace evadir essas definições (cf. Pignarre \& Stengers 2011:32).

As implicações desses "atos de contenção" são bastante conhecidas entre as populações atingidas por grandes empreendimentos, em razão de serem exatamente esses movimentos que possibilitam estabilizar a dimensão destrutiva do capitalismo sobre suas vidas em uma rotina prática. Eles são as condições para a criação de um regime discursivo que legitima a violência. Na realidade, a violência exercida pela prática da análise ambiental de grandes empreendimentos não é sequer vista como violência, mas como medidas regulares ou administrativas (racionais) da prática da política do licenciamento ambiental (cf. Nixon 2011). Acredito que essas contenções sejam uma das causas do mascaramento dessa violência, bem como da subsunção do sofrimento social a que são acometidos os atingidos por barragens pelos processos normativos e institucionais da prática do indigenismo empresarial ${ }^{12}$.

Contudo, a pergunta que se coloca é: como a reprodução dessa estrutura regimentar destrutiva e violenta é experimentada pelas pessoas - e não apenas os sujeitos cognoscentes chamados

12 Para uma análise dos processos científicos, normativos e institucionais que subsumem ou obscurecem as dimensões do sofrimento social das populações atingidas por barragens, ver Magalhães (2007). 
para operacionalizar essas decisões na qualidade de "analistas ambientais" ou "indigenistas empresariais" - no seu campo de atuação? Como são definidos os relacionamentos desses profissionais com o campo mais imediato de sua experiência, frente às divergências, às contradições, à dúvida $\mathrm{e}$ às incertezas por eles vivenciadas e colocadas pelas populações atingidas por tais empreendimentos? Seria possível a "realidade" de sua interação com essas populações e seus ambientes ser reduzida aos procedimentos e práticas definidos por uma circunstância externa, supralocal?

É preciso mapear o modo como os analistas ambientais se movem por entre os percalços e as contenções, exigidas pela sua atuação profissional. Nesse mapeamento, é possível romper com o silêncio desses trabalhadores, que, protegidos por forças políticas, econômicas e científicas muito poderosas, são coprodutores da dor e do sofrimento impostos às populações atingidas pelos megaempreendimentos.

\section{O GOVERNO DOS CONSULTORES AMBIENTAIS: OS MODOS DE REPRESENTAÇÃO E DE RELACIONAMENTO DA PRÁTICA DA POLÍTICA DO LICENCIAMENTO AMBIENTAL}

O antropólogo Tim Ingold (2002), certa vez, escreveu sobre uma situação próxima à divergência observada entre os Xikrin e os consultores ambientais, em Belo Monte, ao constatar a existência de duas explicações, por um lado, feitas por biólogos, por outro, pelos povos Cree, da região nordeste do Canadá, para o comportamento dos caribu (ou rena): animais que permanecem estáticos, ao invés de correrem, quando deparados com um caçador na floresta. Segundo Ingold (2002:13-16), os biólogos atribuem esse comportamento à adaptação dos caribu à predação dos lobos, pois, quando param, o lobo que os perseguia também para. Este seria um momento em que ambos administram a retomada de fôlego para a fase final e decisiva desse episódio, o ataque do lobo e a fuga dos caribu. Do ponto de vista dos Cree, a parada das renas diante dos caçadores é um momento em que o animal se oferece a seu predador, um tanto que intencionalmente e em um espírito de boa vontade, até mesmo de amor (Ingold 2002).

Ingold (2002) estabelece, ainda, um terceiro ponto de vista para a explicação dessa situação: o dos antropólogos culturais. Segundo o autor, os antropólogos descartariam o julgamento sobre a veracidade de ambas as posições, em favor da "compreensão do que elas significam, dado o contexto no qual são desenvolvidas"13 (Ingold 2002:14). Isso permitiria voltar a atenção menos para "a realidade tal como ela é"; a forma como a natureza realmente funciona (o ponto de vista "objetivo" dos biólogos), e mais para os "diversos modos nos quais os constituintes do mundo natural figuram no imaginário, ou nos assim chamados mundos cognoscíveis dos sujeitos culturais" ${ }^{14}$ (Ingold 2002:14).

No entanto, ainda segundo o autor, se a abordagem antropológica torna possível

13 "The anthropologist's first concern is not to judge the truth of the proposition but to understand what it means, given the context in which it is advanced" (Ingold 2002:14).

14 "[...] the diverse ways in wich the constituents of the natural world figure in the imagined, or so-called 'cognised' worlds of cultural subjects" (Ingold 2002:14). 
problematizar as "descrições de valor neutro do mundo físico", presentes nas explicações meramente comportamentais dos biólogos sobre a reação dos caribu, por outro lado, seus apontamentos, restritos aos termos dos "mundos discursivos de significância culturalmente construída" - nos quais os caçadores Cree, supostamente, narrariam e interpretariam seus encontros com os caribu nos termos de um "sistema de crenças cosmológicas" -, acabam por estabelecer um conhecimento de tipo formal e autorizado, transmissível em contextos desconectados da relação que os Cree estabelecem com os caribu, tal como fazem os biólogos.

Ora, se a relação que se estabelece entre os caçadores, as renas, os biólogos e os antropólogos é demarcada pela presença de todos no mundo, tanto as explicações comportamentais dos biólogos como aquelas baseadas nos "mundos significativos"15 dos antropólogos resultariam em uma "abordagem autoritária de como a natureza realmente funciona" (Ingold 2002:15), a qual, por fim, convalidaria o "duplo desengajamento do observador com o mundo" (Ingold 2002:15), tal como o estabelece a razão abstrata do pensamento ocidental.

Nesse sentido, as explicações dos antropólogos de que "diferentes repertórios culturais percebem a realidade de modos diferentes a partir do momento em que processam os mesmos dados da experiência nos termos de quadros alternativos de pensamento ou esquemas de representação"16 (Ingold 2002:15) não só subscrevem, como reforçam a visão das ciências naturais. Afinal, a ideia de "diferentes visões de mundo" também fundamenta a "construção específica de uma realidade externa”, estabelecida para além da pessoa humana e de sua relação com o mundo. Segundo Ingold (2002), é exatamente o deslocamento do observador do mundo promovido por ambas as explicações que deve ser superado, se quisermos nos recolocar no engajamento ativo e contínuo com nossos ambientes.

A proposição de Ingold (2002) fornece-nos uma nova compreensão para a distinção entre os posicionamentos dos Xikrin e dos consultores ambientais sobre o destino do rio Bacajá, após a instalação de Belo Monte, pois a sua explicação não nos autoriza a buscar uma comparação para essa divergência a partir da reprodução de diferentes quadros ou modelos interpretativos da realidade; muito menos nos permite considerar que tais modelos interpretativos são construídos desde uma realidade externa, onde o princípio dessas distinções estaria ancorado nos modos correspondentes à forma como cada grupo ordena as suas observações do mundo, com base em distintos processos, funções ou níveis estratégicos.

Nesses termos, considerando a evidência da presença de ambos, consultores e indígenas, no rio Bacajá, o que se pode perceber como distinto, no posicionamento dos Xikrin e dos consultores ambientais, é o modo correspondente à maneira como cada um desses grupos se relaciona com o rio. Trata-se de uma relação que não se estabelece a partir da oposição de duas visões de mundo ou de projetos perseguidos, mas sim de dois modos de relacionamento com o mundo, cujos sentidos, tanto em uma como na outra posição, não devem ser ignorados.

15 Para utilizar uma expressão de Clifford Geertz (2000:151).

16 "[...] that people from different cultural backgrounds perceive reality in different ways since they process the same data of experience in terms of alternative frameworks of belief or representational schemata" (Ingold 2002:15). 
Sendo assim, o que deve ser resgatado é o lugar primordial que tais sentidos ou sentimentos humanos ocupam nas formas de expressão desse relacionamento ou dessa interação com a natureza, tanto no posicionamento Xikrin como no dos consultores ambientais. Ingold (2002) argumenta que a narrativa dos Cree sobre o seu encontro com o caribu - o momento em que esses animais se oferecem ao caçador, na floresta, em um ato de boa vontade, até mesmo de amor -, "dá forma a um sentimento humano" (Inglod 2002:25). Neste caso, destacamos "o sentimento da proximidade vívida [junto] dos caribu como um outro ser vivo, sensível” ${ }^{\text {"17 }}$ (Inglod 2002:25), um "modo ativo, perceptivo de engajamento, um meio de estar literalmente 'em contato' com o mundo"18 (Inglod 2002:23). E é nesta chave que busco problematizar as distintas expressões e modos de conhecimento que orientam os posicionamentos assinalados pelos Xikrin e pelos consultores ambientais sobre o destino do rio Bacajá.

Afinal, a narrativa dos Xikrin de que "o rio Bacajá vai secar, todos os Xikrin sabem, mas vocês não querem acreditar", tal como a narrativa dos Cree, dá forma a um sentimento humano. Nessa expressão, o rio torna-se vívido, próximo, sensível, percebido, ativo, em contato. Na medida em que, na formulação dos consultores ambientais, sem querer privar essas pessoas de sentidos, existe a tendência de estranhar esses sentimentos em favor de outros, isto é, a tendência de substituir toda a relação expressa em vivacidade, sensibilidade, atividade e contato pela indiferença, pela apatia, pela frieza, pelo desprendimento e pela descontinuidade.
Na percepção do analista ambiental:

O rio Bacajá não irá secar, mas a sua
navegabilidade será comprometida,
os fluxos migratórios de espécies de
peixes serão afetados, bem como seus
processos reprodutivos, a diversidade
de espécies encontrada no interior da
TITB será reduzida, a velocidade do
escoamento fluvial comprometerá a
estabilidade das suas encostas, enfim, o
mundo tal como os Xikrin o conhecem,
e que os consultores registraram em
determinado momento de seu trabalho,
não será mais o mesmo.

Nessa relação, todo o comprometimento com a manutenção dos modos de vida Xikrin exigidos pela prática da análise ambiental parece dispensar uma série de aspectos registrados por estes profissionais ao longo de suas pesquisas de campo. E essa dispensa deveria ser considerada, por parâmetros mínimos de responsabilidade, como uma ofensa à ética destes profissionais. Contudo, sem a pretensão de ditar padrões normativos éticos para a consultoria ambiental, talvez seja oportuno interrogarmos sobre os processos por meio dos quais essa dispensa é assegurada.

Afinal, se os modos de relacionamento exigidos pela prática da consultoria ambiental são definidos por operações de sentidos que tendem a desarticular a experiência de campo dos profissionais da consultoria ambiental, em um deslocamento que coloca em perspectiva não os modos de vida material e espiritual das comunidades indígenas, nem mesmo

17 "[...] in this case the feeling of the caribou's vivid proximity as another vivid, sentient being" (Inglod 2002:25).

18 "[...] is a mode of active, perceptual engagement, a way of being literally 'in touch' with the world" (Inglod 2002:23). 
as interações mais próximas com os ambientes de atuação desses profissionais (e.g., a Volta Grande do rio Xingu), mas sim uma realidade conectada a processos estabelecidos desde outro lugar, uma pergunta se faz necessária: como tal relacionamento, que se estabelece de modo indiferente às aflições dos Xikrin com relação à usina Belo Monte, é experimentado pelos consultores ambientais? Como tal experiência é processada pelos consultores ambientais, a despeito de toda a interação desses profissionais com o rio Bacajá, com o rio Xingu e com os modos de vida das populações que ali habitam?

Nessa proposição, a atenção retorna aos mediadores da atividade dos consultores ambientais, isto é, ao conjunto de técnicas e práticas de produção de conhecimento por eles utilizado para sustentar e reificar seus posicionamentos, não apenas para fundamentar a maneira como suas formas de expressão produzem um "nível de realidade" à parte, ordenado pela intervenção do Estado na região da Volta Grande ${ }^{19}$, de modo a mascarar os impactos desmedidamente nefastos de uma grande usina hidrelétrica, neutralizar os seus críticos, apaziguar os conflitos e contornar as perplexidades que tais empreendimentos geram.

Se o retorno a esses mediadores permite denunciar os limites do Estado, essa denúncia deve ser também buscada nos limites impostos aos sentidos humanos pelos atos de contenção da prática da política do licenciamento ambiental. Afinal, se a intervenção que o trabalho desses profissionais busca estabelecer se ampara na indiferença, em um movimento cujos relacionamentos micropolíticos cedem espaço para a expressão dos campos formais, autorizados, supralocais, criados para transmitir o conhecimento adquirido no campo em contextos mais além da sua experiência imediata, a ética a ser buscada por (e para) esses profissionais deve iniciar pela inauguração de um estado de crise para consigo mesmos, isto é, pela criação de uma relação crítica para com os padrões normativos que, em determinado momento histórico, designaram essas pessoas a reproduzirem tecnologias e procedimentos de governo de modo objetivo, suprassensível, desumano, impessoal, imparcial ou desinteressado.

No caso dos ECRB, foi exatamente a reprodução dessas tecnologias e desses procedimentos que permitiu, pelo menos para os consultores ambientais e suas redes de relacionamento ${ }^{20}$, afirmar o posicionamento de que o rio Bacajá não iria secar. $\mathrm{Na}$ formulação dos consultores ambientais, era a objetividade científica da modelagem matemática, expressa por meio de imagens gráficas, cujo esquema representava a simulação das condições do rio Bacajá com e sem usina (Figuras 3 e 4 ) 21 , o que permitia a esses profissionais afirmarem o seu posicionamento, na medida em que desarticulavam o contraponto dos Xikrin.

19 Um "nível de realidade" que se materializa por meio de uma série de processos, procedimentos e práticas específicos de governo, tal como nos demonstrou Michel Foucault, a partir do conceito de "governamentalidade do estado" (cf. Foucault 2002, 2008).

20 Nas quais estão inclusas a FUNAI, o IBAMA, a Norte Energia e seus investidores, a Agência Nacional de Energia Elétrica (ANEEL), enfim, toda a rede de poder supralocal que é criada a partir da prática do licenciamento ambiental.

21 Para a compreensão de como as simulações das condições hidrológicas do rio Bacajá "com e sem a usina" foram alcançadas, ver nota 11 deste artigo. 


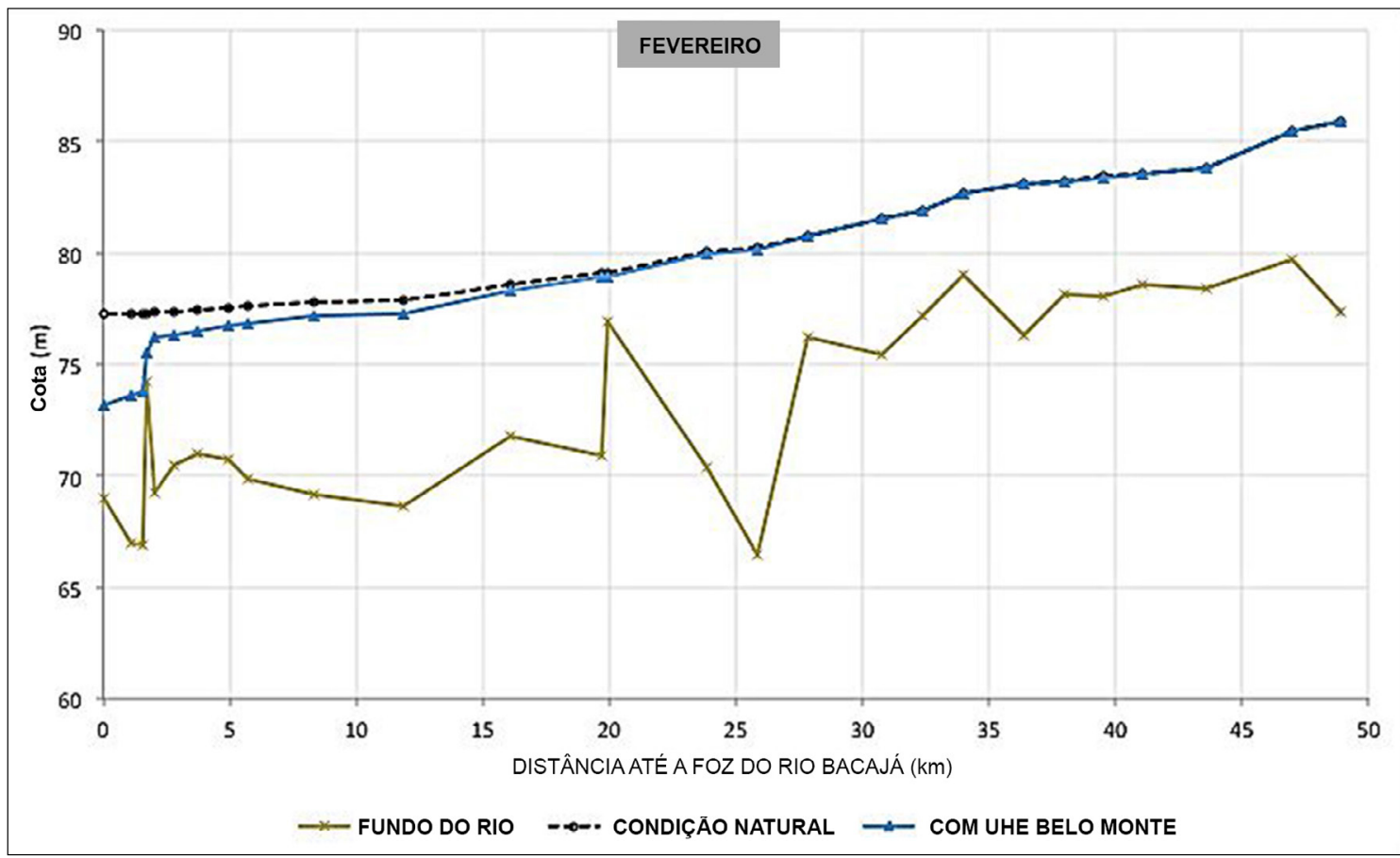

Figura 3 - Linhas d'água simuladas para o mês de fevereiro (condição natural e com Belo Monte), cenário de vazões médias. Fonte: Norte Energia (2012a).

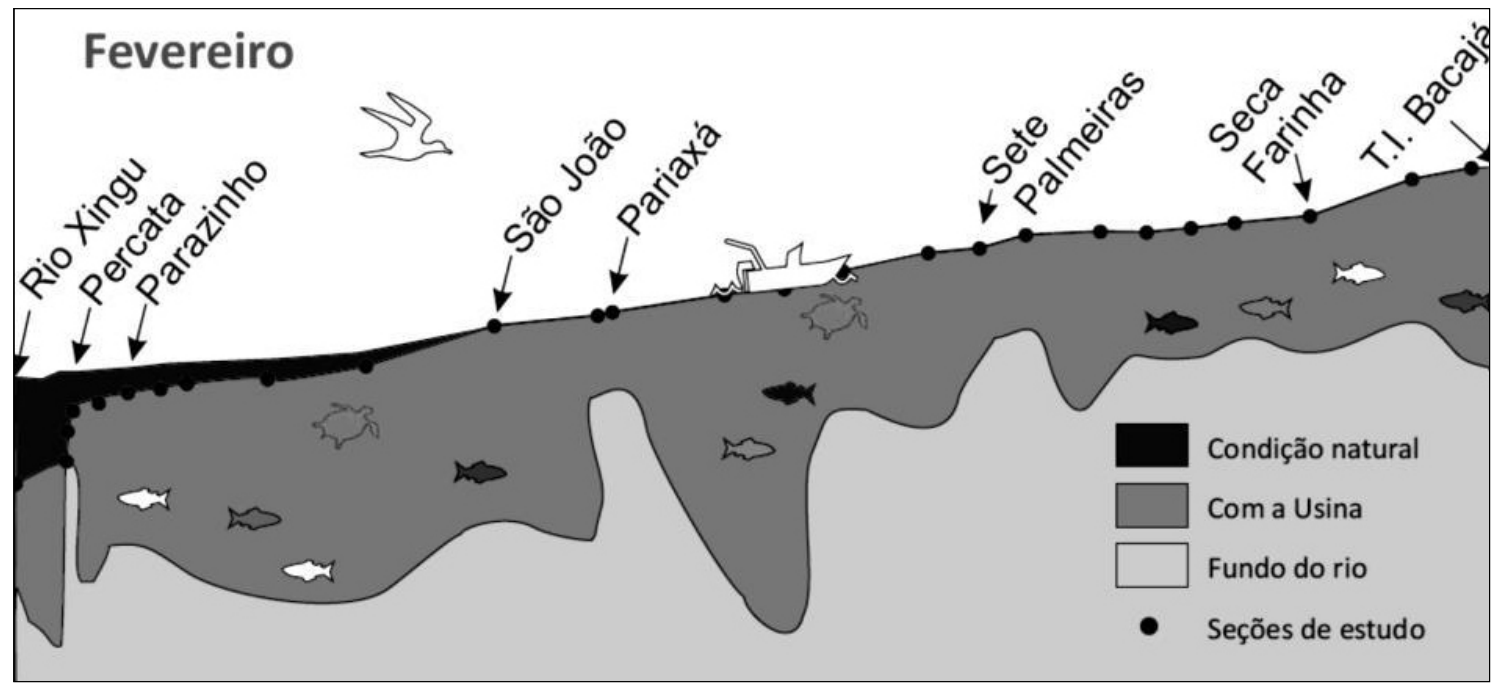

Figura 4 - Linhas d'água simuladas para o mês de fevereiro, cenário de vazões médias. Trecho de pôster utilizado durante a apresentação dos resultados dos ECRB na TITB.

Fonte: Norte Energia (2012a; imagem colorida no original). 
Foram as imagens gráficas anteriormente representadas que permitiram aos ECRB e seus autores chegarem à conclusão já referenciada, de que o

\section{[...] maior impacto simulado (a diferença entre a condição natural e a condição com usina) mostra que a perda de efeito de remanso chega[ria] até [...] cerca de $28 \mathrm{~km}$ da foz do rio Bacajá [local onde está situada a corredeira Pariaxá, Figura 4], ou seja, não se espera impacto sobre o rio Bacajá dentro da TITB, que está a cerca de 50 $\mathrm{km}$ da foz do rio (Norte Energia 2012a).}

Enfim, o que informa a reprodução das tecnologias e dos procedimentos da política do licenciamento ambiental de megaempreendimentos na Amazônia é um processo de racionalização da vida, instrumentalizado pela economia, o qual, segundo Michel Foucault (1999, 2002, 2008), permite ajustar os fenômenos sociais e naturais de determinado território aos processos econômicos de interesse do Estado, por meio de mecanismos de poder-saber bastante específicos. No caso de Belo Monte, a novidade de tal processo está no papel assumido pelos consultores ambientais no exercício desse governo econômico, bem como na sua capacidade, por meio do conhecimento experto, de definir a sua realidade ${ }^{22}$.

Ademais, se esse movimento de racionalização aparece como uma abstração separada de uma ordem social definida, tal como nos revela Timothy Mitchell (2002, 2011, 2014) (a separação que o pensamento da consultoria ambiental faz da prática social e dos modos de vida dos Xikrin no rio Bacajá), ou se esse processo é marcado pela exclusão e pelo mascaramento da violência sobre modos de vida bastante particulares (Baines 2004:36; 2012:109-110), é porque, na história recente do capitalismo, as práticas sociotécnicas que convencionaram a separação entre a natureza e a cultura - ancoradas em interesses econômicos exclusivos - estão cada vez mais organizadas, coordenadas e efetivas (cf. Mitchell 2002, 2011).

Em uma etnografia recente sobre o papel do conhecimento produzido por consultores (ou experts) no contexto de um projeto de "desenvolvimento" na Índia rural - o Indo-British Rainfed Farming Project (IBRFP), executado pela Agência Britânica de Cooperação para o Desenvolvimento (UK Department for International Development - DFID) -, o antropólogo David Mosse (2005) afirma que o trabalho desses profissionais no campo operativo das políticas públicas para o desenvolvimento é mais conceitual do que prático.

Segundo o autor, embora os "modelos interventivos" criados pelos consultores em desenvolvimento, nas suas diferentes frentes de atuação (e.g. economia, ciências do solo e genética vegetal, antropologia social etc.), fundamentassem-se em dados empíricos das

22 Afinal, a inclusão das variáveis naturais do rio Bacajá aos cálculos dos profissionais da consultoria não preenche outra função além da fundamentação do interesse do Estado de explorar a região da Volta Grande do rio Xingu para geração de energia elétrica, tal como havia sido estabelecido pela Resolução n. 6 do Conselho Nacional de Política Energética (CNPE), de julho de 2008, a qual indicava “o interesse estratégico do rio Xingu para fins energéticos”, ao lado das estratégias de "conservação, diversidade biológica e da proteção da cultura indígena. 
realidades trabalhadas, eles não eram dirigidos para o desempenho de práticas particulares, mas sim para o estabelecimento de um marco gerencial, ordenado a partir de rotinas organizacionais e relacionamentos políticos supralocais, sustentados menos pelo controle das ações por parte das comunidades rurais de 'beneficiários' do que pelas relações entre a Agência Britânica e suas instituições parceiras, tais como a $\mathrm{KBCL}^{23}$, uma cooperativa indiana de fertilizantes.

A grande contribuição do livro de Mosse (2005) - que se estrutura a partir da autoetnografia de seu envolvimento direto e regular (entre os anos de 19901997) no IBRFP, atuando como consultor antropológico nos processos de 'planejamento participativo' das ações do projeto - está na maneira como sua análise evidencia as formas como os "modelos das políticas públicas para o desenvolvimento", encobertos por incertezas, mas legitimados pelo conhecimento experto, não são desenhados para transformar a política em realidade, mas para justificar regras e procedimentos normativos de governo desmembrados do contexto de sua atuação (Mosse 2005:157-183).

Nesse processo, o que está em jogo é o modo como o aparato conceitual dos consultores - i.e., os mediadores da sua atividade profissional, atendendo à finalidade específica de racionalizar, estabilizar e autorizar determinadas representações econômicas sobre eventos, atos e sentimentos; e ordenados a partir de redes de poder supralocais - deslocam as articulações possíveis que esses profissionais poderiam estabelecer com o campo mais imediato de sua atuação.

Como colocou David Mosse (2005), numa avaliação crítica da sua atuação no IBRFP:

\begin{abstract}
Nossa escrita, modelos e mapas desmanchavam os agenciamentos pessoais, híbridos e contingentes, bem como nossas conexões, lutas e interações com a prática concreta ao representar os eventos como resultado de uma intensão racional guiada pelo conhecimento especializado (Mosse 2005:270).
\end{abstract}

É esse processo de deslocamento da vida social mais imediata, vivenciado pela relação dos consultores ambientais com seus interlocutores no campo de sua atuação, permitido por um trabalho de representação capaz de definir a realidade de uma região nos termos econômicos, que torna tão poderoso o trabalho da consultoria ambiental na sua fundamentação do interesse de Estado. Ora, no caso de Belo Monte, os consultores ambientais assumiram um papel decisivo para a "viabilização sociopolítica" do megaempreendimento ${ }^{24}$.

23 O significado por extenso desta sigla não é apresentado no livro de David Mosse (2005). A sigla indica apenas uma "cooperativa nacional de fertilizantes, um dos parceiros do UK Department for International Development (DFID) na execução do Indo-British Rainfed Farming Project (IBRFP).

24 A expressão "viabilização sociopolítica” de Belo Monte é registrada pela primeira vez no relatório final do Grupo de Trabalho (GT) Belo Monte, criado pelo Departamento Nacional de Águas e Energia Elétrica (DNAEE), em 1994, com o objetivo de atualizar e complementar os estudos de viabilidade de Belo Monte, concluídos em 1989. Entre as recomendações do GT, expressas no seu relatório final publicado em 1995, estava a "elaboração e implantação simultânea de um programa de viabilização sociopolítica do empreendimento [...] com indicação de procedimentos visando obter um relacionamento com a sociedade em busca de participação e apoio" (Eletrobrás 2009a:30-32; grifo meu). O Estudo de Impacto Ambiental (EIA) de Belo Monte, iniciado em 2002 e concluído em 2009, a despeito da 
Por outro lado, embora o trabalho dos consultores ambientais, ainda que economicamente orientado, seja sempre o resultado da interação do humano e do não humano, do orgânico e do técnico, do programado e do não previsto ${ }^{25}$, a separação que os resultados de suas representações fazem da realidade mais próxima de sua interlocução não pode ser dispensada. Afinal, é exatamente essa separação que a história recente do capitalismo nos revela, como assinala o historiador Timothy Mitchell (2011:269):

Ao longo do último século, mais e mais trabalho foi feito para produzir representações da natureza e para produzir o que aparece como uma separação progressivamente mais distinta entre essas interações a que chamamos de natureza e aquelas que organizamos como imagens da natureza. Seu resultado foi a abertura, por uma série de mudanças, desvios e atrasos, para o que aparece como uma distância cada vez mais eficaz entre nossos encontros com as forças naturais e nossos encontros com os relatórios e imagens daqueles encontros. É importante entender a produção dessas remoções e atrasos e os tipos de separação que eles efetuam. Dispensar tais remoções e separações como um falso binário (ainda que seja melhor que assumir o dualismo simples da natureza versus a representação) pode negligenciar a tarefa de rastrear como tais remoções e separações foram produzidas.

Os trabalhos de representação da natureza pela prática da consultoria ambiental, por meio de imagens gráficas, mapas, relatórios, são, definitivamente, modos eficazes de produzir e promover o distanciamento entre natureza e cultura. As mudanças, os desvios e os atrasos que tais representações fazem do nosso encontro com as forças naturais, a fim de fundamentar interesses econômicos, endereçam a razão de sua finalidade. Se, como apontou Giorgio Agamben (2007), a operação de incluir a vida nos mecanismos e cálculos do poder estatal implica uma relação de exclusão, onde as próprias condições do corpo vivente humano thes aparecem como opostas e separadas, como algo que não pode ser assumido integralmente e que, por isso, deve ser excluído, no trabalho da consultoria ambiental, essa relação de exclusão aparece como a condição para a atuação profissional.

Se, por um lado, decisões como a instalação de Belo Monte podem ser sustentadas apenas mediante a participação em uma rede ampla de relações institucionais, informada por papéis morais, historicamente constituídos e reificados em processos e procedimentos operacionais

\footnotetext{
legislação ambiental no Brasil, é resultado desse processo de "viabilização sociopolítica" da usina, que até o início da década de 90 fora marcado por grande contestação das comunidades locais, sobretudo as comunidades indígenas. Isto é, Belo Monte é um empreendimento econômico do Estado brasileiro que só se tornou "viável" pelo trabalho interpretativo dos consultores ambientais, organizados em torno das práticas da política do licenciamento ambiental.

$25 \mathrm{O}$ trabalho de construção de barragens, projetos de reflorestamento, irrigação de áreas desérticas e de administração de comunidades rurais é sempre orientado por formas de representação da natureza que derivam de uma variedade de interações técnico-orgânicas e de práticas sociotécnicas - a escrita, os registros, as projeções e referências -, que não estão separadas em um plano imaterial (cf. Mitchell 2011).
} 
culturalmente consolidados, o discurso como o "rio Bacajá não irá secar" pode ser proferido, a despeito de toda a desarticulação de modos de vida que tais decisões e discursos representam. Por outro lado, a evidente eficácia das redes de poder que se estruturam em torno do campo da política do licenciamento ambiental requer a potência de uma outra relação. Afinal, o que está em jogo é a forma como essas redes, a partir de modos bastante específicos de relacionamento com o ambiente - possibilitados por práticas sociotécnicas instrumentalizadas pela economia e deslocadas de contextos sociais particulares -, criam um nível de realidade que desconecta as pessoas dos contextos relacionais mais próximos de sua interlocução, produzindo, assim, a indiferença ${ }^{26}$.

Esse texto é uma tentativa de reflexão sobre como os modos de relacionamento, expressão e conhecimento operados pelos consultores ambientais, em contraposição aos modos de relacionamento, expressão e conhecimento operados pelos Xikrin do Bacajá, são marcados pela indiferença. Contudo, os esforços aqui empregados buscam também problematizar ${ }^{27}$ como esses fatores, quando característicos da prática da consultoria ambiental estabelecida a partir da separação natureza/cultura, têm prejudicado a nossa relação com nós mesmos.

Afinal, de quantas formas nós (profissionais que, em algum dia, nos engajamos com a prática da consultoria ambiental ou qualquer outra prática da política do licenciamento ambiental de grandes empreendimentos) herdamos na carne os desenvolvimentos turbulentos e desagradáveis do capitalismo?

Nesse sentido, a questão se volta para a forma como um sistema representativo, autorizado a conduzir os sujeitos e as práticas nos contextos da instalação de megaempreendimentos - expresso na forma do indigenismo empresarial ou na forma da política do licenciamento ambiental -, pode coexistir com as aflições das populações afetadas por tais empreendimentos, de modo indiferente a todas as evidentes perdas (sociais e ambientais) que esses posicionamentos institucionais subscrevem.

O que passa na introspecção coletiva destes profissionais quando as convenções sociais por eles veneradas - tal como a informada pelo aparato ideológico edificado em torno da política do licenciamento ambiental - são atravessadas pelas incertezas e aflições presentes no campo de sua atuação? ${ }^{28}$ Por outro lado, o que se passa na privacidade da introspecção coletiva destes profissionais quando suas identidades, suas

26 Tema a que Gustavo Lins Ribeiro (1988), de certa forma, já se aproximava, na sua leitura dos processos sociais e de poder que permitiram a implantação da usina hidrelétrica Yacyretá, no rio Paraná, na fronteira da Argentina com o Paraguai, ao caracterizar, entre as dimensões sociais essenciais para a sustentação destes empreendimentos, o marco "temporal" dos fluxos migratórios da sua força de trabalho como um dos fatores que desestimulam os indivíduos engajados nesses fluxos transitórios a conceberem sua experiência mais próxima como permanente, tanto no nível profissional quanto familiar (Ribeiro 1988:156-171).

27 À luz de Donna Haraway (2003) e Isabelle Stengers (2017)

28 A formulação desse questionamento se deve à leitura de Michael Herzfeld (2008) e de seu conceito de dissemia, definido enquanto "a tensão formal ou codificada entre a autoapresentação oficial e o que vai passando na privacidade da introspecção coletiva” (Herzfeld 2008:31; itálico no original). Segundo o autor, "Embora o aspecto oficial seja um 
convenções de autojustificação e modelos de existência social deparam-se com os sentidos práticos locais, os quais passam a ser por eles vivenciados (in)conscientemente na sua experiência sensorial, durante o trabalho de campo, junto às populações afetadas por grandes empreendimentos?

Afinal, o que, de fato, acontece com o consultor ambiental no campo da sua atuação é a experimentação de um "domínio social" (Latour $2005)^{29}$ ou relacional, cujos sentidos e efeitos percebidos "mobilizam seu próprio estoque de imagens" (Favret-Saada 2005:159), de modo que a "carga energética" a que são expostos esses profissionais no campo da sua atuação, tomando de empréstimo o texto de Favret-Saada (2005:159), causam um distúrbio provisório de percepção, uma quase alucinação, ou uma modificação das dimensões; ou, ainda, a sensação de estar submerso num sentimento de pânico, ou de angústia maciça.

Ora, em todo o meu envolvimento com os modos de vida Xikrin e com suas dinâmicas de navegação fluvial, acabei por ser direcionado "a uma variedade particular de experiência" (FavretSaada 2005:159), cujos sentidos o meu corpo passou a processar. Nesse contexto relacional, as categorias da política do licenciamento ambiental não figuravam como bons guias para a minha experiência pessoal, na medida em que "a crença de que era possível reduzir os efeitos sociais produzidos [por Belo Monte]" (Bronz 2016:43) se desfez, as posições de poder se estremeceram e a imaterialidade da mercadoria se desligou, de modo a ativar outros agenciamentos do cosmos, cujos termos classificatórios buscavam ansiosamente outra expressão, que não a indiferença.

Recordando, foram mais de 2.500 quilômetros percorridos pelos rios Xingu e Bacajá somente em 2012, contabilizando apenas o trajeto entre a cidade de Altamira até as cinco aldeias da TITB e os deslocamentos locais no interior da TI, fora outros percursos realizados na Volta Grande para mapeamento da navegação das populações ribeirinhas locais. Longas conversas com os Xikrin, entre outros moradores da região, foram conduzidas, a fim de caracterizar as dinâmicas da navegação fluvial. Os canais de navegação dos rios Xingu e Bacajá foram percorridos e as dificuldades para transpor suas corredeiras nos períodos de seca, bem como para enfrentar os rebojos, as neblinas ou as fortes chuvas durante a cheia foram vivenciadas (Figura 5). Durante os meus levantamentos, foi experimentado todo o “sistema de aprendizado" (Ingold 2002:37) dos navegadores dos rios Xingu e Bacajá, praticamente engajados com os movimentos hidrológicos desses rios, o que os permitia navegar durante todo o ano, independente das dificuldades impostas pelos ciclos hidrológicos locais (cheia, vazante, seca e enchente) ${ }^{30}$.

Contudo, toda essa rede de relações estava sendo contrastada por um único evento possível: a instalação

objeto legítimo (e de fato necessário) de análise etnográfica, a intimidade que ele mascara é o sujeito de um profundo sentido de vulnerabilidade cultural e política" (Herzfeld 2008:31).

29 Considerando aqui a pressuposição de Latour (2005:6), de que o domínio social é muito mais extensivo do que a tentativa de limitá-lo à esfera dos humanos e das sociedades modernas.

30 Tais como o conhecimento sobre as pedras "não marcadas” no fundo dos rios Xingu e Bacajá, as informações 


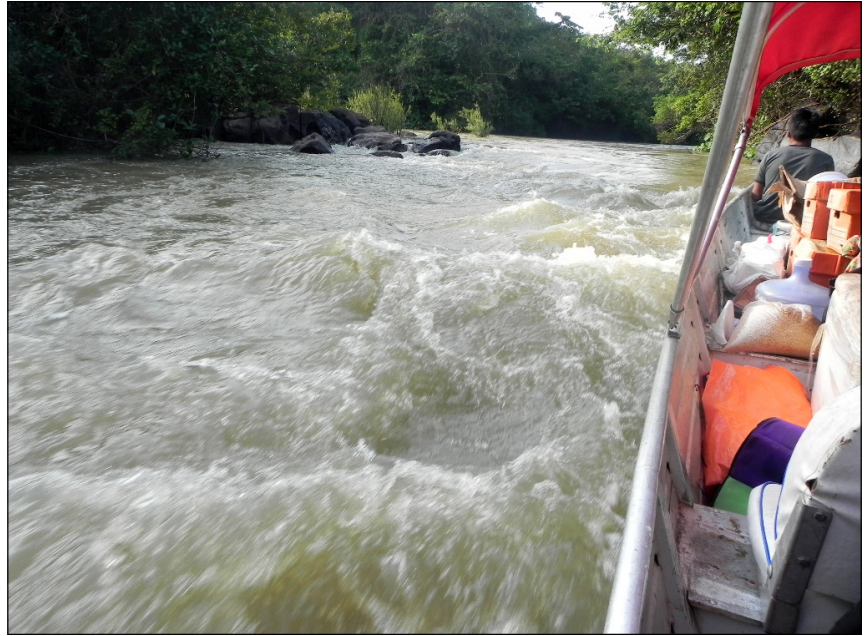

Figura 5 - Corredeira Jericoá, no rio Bacajá, localizada no interior da TITB, a aproximadamente $60 \mathrm{~km}$ da foz. Registro feito durante o período de seca, no mês de outubro de 2012. Vazão registrada em $910 \mathrm{~m}^{3} / \mathrm{s}$. Nesse trecho, durante o mapeamento, enquanto o piloto

Xikrin acionava o motor $15 \mathrm{HP}$ do barco para subir o rio, e seu filho aproava a embarcação com a ajuda de uma "vara de pau", eu puxava o barco com a ajuda de uma corda, em um ponto seguro a montante da cachoeira. Essa era a única forma de vencer esse trecho fluvial no período de seca. Foto: Rafael Costa (2012). da vazão reduzida na Volta Grande alargar os tempos dos deslocamentos. Essa angústia (tanto minha como dos Xikrin e demais navegadores da região) deveria ser sanada na reprodução da dinâmica proposta pelo monitoramento ambiental da navegabilidade e da acessibilidade regional. Por mais que eu soubesse que as dificuldades à navegação mais comuns na Volta Grande e no rio Bacajá se davam nos períodos de estiagem, em função da redução natural da vazão do rio, do estreitamento dos canais navegáveis e da formação de fortes corredeiras em trechos com declives relativamente acentuados, e que essas dificuldades seriam intensificadas a partir da imposição da vazão reduzida na região, a ideia de propor alternativas de acesso à TITB, como a construção de estradas, sabendo que isso poderia ocasionar da usina Belo Monte. E esse contraste, marcado pela dimensão destrutiva que Belo Monte representava sobre a experiência prática das populações da Volta Grande, me levava a querer evitar as mensagens abertamente contraditórias, proferidas pelas políticas de indigenismo empresarial e do licenciamento ambiental, as quais eram fonte de uma sensação de pânico e desespero, pois: por mais que experienciasse as longas jornadas de navegação nos rios Xingu e Bacajá - que num percurso fluvial de $350 \mathrm{~km}$, distância entre a cidade de Altamira até a aldeia mais a montante da TITB, durante o ciclo hidrológico de seca, chegava a durar dois dias e meio de viagem -, poderia ser atormentado pela possibilidade da imposição maior fluxo de caçadores, madeireiros e garimpeiros ao território indígena, me parecia absurda. Por mais que eu aprendesse sobre as denominações dos furos, dos igarapés, dos igapós, dos poções, das ilhas, das cachoeiras e dos largos da Volta Grande e conhecesse seus respectivos usos privilegiados em cada uma das épocas do ano para caça, coleta, roça, pesca de bagres ou peixes ornamentais, e pudesse ser atormentado pela alteração ecológica que a vazão reduzida iria representar na reprodução destes ecossistemas e dos modos de vida relacionados, essa aflição deveria ser contida pela estrutura objetiva dos procedimentos da política do licenciamento ambiental.

sobre a velocidade a empregar na descida de corredeiras ou quando usar cordas para subi-las nos ciclos de seca, a indicação dos locais que regulavam o tempo da viagem, as ilhas mais apropriadas para a pernoite durante longos deslocamentos, para não "toparmos com a onça", enfim, todas as suas respostas sociais às condições naturais da Volta Grande, as quais permitiam a perenidade da atividade durante todo ano. 


\section{AS CATEGORIAS SOCIAIS E AS 'ALTERIDADES SIGNIFICANTES' NO CAMPO DE ATUAÇÃO DOS CONSULTORES AMBIENTAIS}

Donna Haraway (2003), tomando como exemplo o conceito de "ontologias emergentes", de Helen Verran, faz uma pergunta obrigatória: como pode o conhecimento geral ser cultivado nos mundos pós-coloniais, comprometidos em levar a diferença a sério? Para a autora, a resposta para essa pergunta só pode ser oferecida em conjunto com práticas emergentes, i.e., no vulnerável, no chão do trabalho que remenda agências não harmoniosas e modos de vida, responsáveis tanto por seus legados históricos discrepantes quanto pela escassa possibilidade, mas absolutamente necessária, de um futuro comum. Segundo Haraway (2003), isso é o que representa alteridade significante. Em outras palavras, é uma forma de construir categorias de modo relacional, e menos discursivo, no sentido foucaultiano.

Contudo, o aferro aos mediadores dos procedimentos científicos da política do licenciamento ambiental, a exegese interpretativa que eles possibilitam, suas "expressões fixas permanentes", suas constituições indiferentes e deslocadas da realidade vivida, bem como as redes de poder que eles sustentam são alguns dos aspectos a impedirem os consultores ambientais de compartilhar um mundo experiencial comum com os indígenas e os demais habitantes (humanos e não humanos) da Volta Grande. As categorias sociais que devem se sustentar para manter a condição social (e de poder) que lhes foi atribuída não podem ser agenciadas pelo mesmo campo de sentidos do ambiente de sua interação, pois, na operação do pensamento profissional da consultoria ambiental, a pessoa humana deve ser deslocada dos efeitos que tal processo classificatório gera sobre o mundo.

O "trabalho categorial" que informa a condição no mundo dos profissionais das consultorias ambientais, ou a sua operação de "criação de mundos (worlding)" (Haraway \& Gane 2009), não é nada relativo. Não porque tal trabalho categorial fuja à interação natureza/cultura, mas porque ele não permite aos consultores ambientais que vivam as consequências de seus atos, tal como os Xikrin as vivenciam. Tal trabalho não permite a eles se situarem inexoravelmente à criação de seus mundos significativos, já que os perigos mortais de suas construções são obscurecidos por um pensamento e uma realidade (econômica) que se sustentam desde outro lugar, que não o da sua experiência mais próxima.

\section{CONCLUSÃO PRIMEIRA: 0 ICONOCLASH XIKRIN OU A SUSPENSÃO DOS ÍCONES DA POLÍTICA DO LICENCIAMENTO AMBIENTAL}

A definição de iconoclash, de Bruno Latour (2008:117, 144), nos informa sobre "aquilo que acontece quando há incerteza a respeito do papel exato da mão que trabalha na produção de um mediador", de modo a redirecionar a atenção para as suas fraqueza e fragilidade. Este é um bom enquadramento para o contraponto Xikrin. Afinal, não é a destruição das imagens produzidas pelos consultores ambientais o que eles pleiteiam com o seu posicionamento, mas a postulação de algo que lhes falta ou que lhes está ausente. Uma imagem "feita em ato", como 
colocou tão bem Thais Mantovanelli (2016a:48), a qual inclua homens e mulheres, constituída através de encontros e engajamentos com parentes, com o rio, com a floresta, com os sonhos e, inclusive, com os consultores ambientais que realizaram por tanto tempo trabalhos de campo na TITB.

Uma imagem feita corretamente, verdadeira, bela, que envolva a alegria de estar junto, feita em conjunto, enfim, uma imagem que promova "ações efetivas no mundo", tal como os Xikrin descrevem nas suas falas (kaben pudjy [fala única, fala reta]), "diferentes das dos brancos... marcadas pela desconfiança e pela mentira” (Mantovanelli 2016a:99, 115). No posicionamento Xikrin, as imagens gráficas apresentadas pelos consultores ocultavam, ao invés de revelarem, os reais efeitos de Belo Monte, pois elas não estavam direcionadas para os índios, para o rio, enfim, para todo o domínio relacional de sua existência, estavam sim voltadas para fundamentar interesses empresarias, orientados pela exploração da região da Volta Grande para fins energéticos.

É contra esse não engajamento das imagens dos ECRB, "fora de seu fluxo" (Latour 2008), i.e., fora dos fluxos contínuos e em movimento do rio Bacajá e dos modos de vida Xikrin, em uma contraposição ao poder de dissimulação de seus modos de vida, que os Xikrin estabeleceram o seu argumento. É contra a possibilidade dos mediadores ou dos produtos do trabalho do indigenismo empresarial prevaricarem a violência de tais empreendimentos que os Xikrin sustentam o seu posicionamento.

\section{CONCLUSÃO SEGUNDA: ENTRE A MÁ CONSCIÊNCIA E $O$ INDIGENISMO ALÉM DO HUMANO}

A tese da "má consciência" foi, certa vez, atribuída ao pensamento indígena da Amazônia, para interpretar sua atitude ambivalente em relação à carne de caça (Hugh-Jones 1996 apud Descola 1998:30). No contexto da relação entre caçadores e presas,

Uma densa rede de interdições e
prescrições alimentares, de procedimentos
rituais de descontaminação e de
dispositivos semânticos de ocultação
deve[ria] atenuar, então, as consequências
da triste obrigação em que se encontram
os homens de destruir vidas animais
para reproduzir a sua. Segundo Hugh-
Jones, essa mistura de reconciliação
e duplicidade com relação ao matar e
consumir o animal não seria própria dos
índios da Amazônia; refletiria um traço
universal da natureza humana e, nesse
sentido, o comportamento dos ameríndios
nada teria de exótico ou arcaico, mas seria
inteiramente homólogo à má consciência
que os ocidentais experimentam
atualmente diante da carne dos açougues
(Descola 1998:30, grifos meus).

No entanto, a disputa semântica ora evidenciada entre os Xikrin e os consultores ambientais sobre o destino do rio Bacajá informanos que a "teoria da má consciência" não é tão universal assim, figurando-se, ainda, como uma das virtudes soberanas da cultura ocidental. $\mathrm{Na}$ afirmação dos Xikrin, de que "o rio iria secar", não há dissimulação da dimensão de perda (e morte) que a instalação de Belo Monte acarretaria aos modos de vida da região da Volta Grande 
do rio Xingu. Essa dimensão dissimulante está exclusivamente evidenciada na relação que os consultores ambientais e indigenistas empresarias estabelecem com os mediadores da produção de seu trabalho social, os quais, materializados em imagens gráficas, provêm um meio eficaz para lidarem com o infortúnio de suas atribuições no marco do capitalismo moderno ${ }^{31}$.

Não se deve ignorar o poder de dissimulação que os instrumentos de trabalho da consultoria ambiental promovem com relação à dimensão de perdas social e ambiental causadas por megaempreendimentos, na sua implicação direta no apaziguamento dos conflitos pessoais e coletivos, vivenciados por estes profissionais na execução de seu trabalho. Afinal, na esteira de Michael Herzfeld $(2008,2016)$, a intimidade que esse poder mascara é muitas vezes a do sujeito de um profundo sentido de vulnerabilidade cultural e política. Interromper esse trabalho de dissimulação é uma proposta muito válida, principalmente quando se tem em pauta não somente o mapeamento dos sentidos de indiferença que são agenciados nessa dissimulação, mas, sobretudo, a proposição de representar outros sentidos, cujos significados podem superar os modos como nossos distanciamentos da natureza têm prejudicado a nossa relação com nós mesmos.

Por fim, se são os indígenas que nos convidam a repensar nossos modos de interação com a natureza, talvez esse seria o momento de propor um novo indigenismo, um "indigenismo emergente", tal como propôs de la Cadena (2010). Um indigenismo para além do empresarial ou do governamental, "com a capacidade de perturbar significativamente as formações políticas predominantes" (de la Cadena 2010:336), tais como o estado, a nação e o desenvolvimento, as quais, amparadas por forças e realidades tecnonormativas poderosas, fazem-nos reproduzir toda a destruição e a violência do capitalismo em um labor diário infernal, que nega seus próprios sentidos, seus efeitos e suas consequências.

\section{REFERÊNCIAS}

Agamben, G. 2007. Homo Sacer: o poder soberano e a vida nua. Belo Horizonte: Ed. UFMG.

Baines, S. G. 1995. Os Waimiri-Atroari e a invenção social da etnicidade pelo indigenismo empresarial. Anuário Antropológico 19(1):127-159.

Baines, S. G. 2004. Antropologia do Desenvolvimento e a questão das sociedades indígenas. Revista Anthropológicas 15(2):29-46.

Baines, S. G. 2012. As usinas hidrelétricas na Amazônia: o indigenismo empresarial e a insustentabilidade de grandes hidrelétricas em terras indígenas, in Desenvolvimento, reconhecimento de direitos e conflitos territoriais. Organizado por A. Zhouri, pp. 98-121. Brasília: ABA.

Bourdieu, P. 2003. Participant objectivation. Fournal of the Royal Anthropological Institute 9(2):281-294. DOI: https://doi.org/10.1111/1467-9655.00150.

31 Como bem apontou Herzfeld (2016), a análise do idioma comum das práticas burocráticas do estado moderno, tais como os expressos nas convenções sociais da "democracia", do "governo racional", da "ciência e tecnologia", do "individualismo", do "compromisso ético e cultural" etc., indica não só a capacidade dessas "entidades imaginárias" gerirem e significarem as identidades pessoais e coletivas, mas a sua capacidade de "provê as pessoas de meios sociais para lidar com o desapontamento" (Herzfeld 2016:11, 16). 
Bronz, D. 2016. Nos bastidores do licenciamento ambiental: uma etnografia das práticas empresariais em grandes empreendimentos. Rio de Janeiro: Contracapa.

De la Cadena, M. 2010. Indigenous cosmopolitics in the Andes: conceptual reflections beyond "politics". Cultural Anthropology 25(2):334-370. DOI: https:// doi.org/10.1111/j.1548-1360.2010.01061.x.

Descola, P. 1998. Estrutura ou sentimento: a relação com o animal na Amazônia. Mana 4(1):23-45. DOI: http://dx.doi.org/10.1590/S010493131998000100002.

Eletrobrás. 2009a. Aproveitamento Hidrelétrico Belo Monte: relatório de impacto ambiental - Rima. Brasília: Leme Engenharia Ltda.

Eletrobrás. 2009b. Estudos etnoecológicos: Estudo de Impacto Ambiental do aproveitamento hidroelétrico (AHE) de Belo Monte. Tomo 5. Brasília: Leme Engenharia Ltda.

Favret-Saada, J. 2005. Ser afetado. Cadernos de Campo (13):155-161.

Foucault, M. 1999. História da sexualidade. A vontade de saber. Rio de Janeiro: Graal.

Foucault, M. 2002. A governamentalidade, in Microfísica do poder, pp. 277-293. Rio de Janeiro: Graal.

Foucault, M. 2008. Segurança, território, população. Curso dado no Collège de France (1977-1978). São Paulo: Martins Fontes.
Fundação Nacional do Índio (FUNAI). 2009. Parecer técnico n. 21: análise do componente indígena dos estudos de impacto ambiental-UHE Belo Monte. Brasília: FUNAI.

Garcia, M. F., I. N. Jezler, M. L. Milazzo, D. J. L. Rocha, S. Froehlich, e C. Vieira. 2009. A influência da componente ambiental na definição do Projeto AHE Belo Monte, in Seminário Nacional de Produção e Transmissão de Energia Elétrica 20:1-8.

Geertz, C. 2000. The way we think now: toward an ethnography of modern thought, in Local knowledge: further essays in interpretative anthropological. C. Geertz, pp. 147-163. Washington DC: Basic Books.

Goffey, A. 2011. Introduction: on the witch's broomstick, in Capitalist sorcery: breaking the spell. Organizado por P. Pignarre e I. Stengers, pp. vii-xxiv. London: Palgrave Macmillan Stengers.

Haraway, D. 2003. The companion species manifesto: dogs, people, and significant otherness. Chicago: Prickly Paradigm Press.

Haraway, D., e N. Gane. 2009. Se nós nunca fomos humanos, o que fazer? Ponto Urbe 6:1-22. DOI: http://dx.doi.org/10.4000/pontourbe.1635.

Herzfeld, M. 2008. Intimidade cultural: poéticas sociais no Estado-Nação. Lisboa: Edições 70.

Herzfeld, M. 2016. A produção social da indiferença: explorando as raízes da burocracia ocidental. Petrópolis: Editora Vozes. 
Ingold, T. 2002. The perception of the environment: essays on livelihood, dwelling and skill. London, New York: Routledge.

Ingold, T. 2003. General introduction, in Companion Encyclopedia of Anthropology. Editado por T. Ingold, pp. xii-xxii. London and New York: Routledge.

Latour, B. 2000. Ciência em ação: como seguir cientistas e engenheiros sociedade afora. São Paulo: Editora Unesp.

Latour, B. 2005. Reassembling the social: an introduction to Actor-Network Theory. Oxford: Oxford University Press.

Latour, B. 2008. O que é iconoclash? Ou, há um mundo além das guerras de imagem? Horizontes Antropológicos 14(29):111-150. DOI: http://dx.doi. org/10.1590/S0104-71832008000100006.

Lévi-Strauss, C. 2016. O pensamento selvagem. Campinas: Editora Papirus.

Magalhães, S. 2007. Lamento e dor: uma análise sócioantropológica do deslocamento compulsório provocado pela construção de barragens. Tese de Doutorado, Departamento deCiências Sociais, Universidade Federal do Pará, Brasil; Universidade Paris 13, França.

Mantovanelli, T. 2016a. Os Xikrin do Bacajá e a Usina Hidrelétrica de Belo Monte: uma crítica indígena à política dos brancos. Tese de Doutorado, Departamento de Antropologia Social, Universidade Federal de São Carlos, Brasil.
Mantovanelli, T. 2016b. Os Xikrin da Terra Indígena Trincheira-Bacajá e os Estudos Complementares do Rio Bacajá: reflexões sobre a elaboração de um laudo de impacto ambiental. Horizontes Antropológicos 22(46):159-188. DOI: http://dx.doi. org/10.1590/S0104-71832016000200006.

Merleau-Ponty,M. 1991.De Mauss a Claude Lévi-Strauss, in Signos, pp. 123-135. São Paulo: Martins Fontes.

Mitchell, T. 2002. Rule of experts: Egypt, technopolitics, modernity. Berkeley, Los Angeles, London: University of California Press.

Mitchell, T. 2011. Afterword: are environmental imaginaries culturally constructed?, in Environmental imaginaries of the Middle East and North Africa: history, policy, power, and practice. Editado por D. Davis e E. Burke, pp. 265-273. Athens: Ohio University Press.

Mitchell, T. 2014. Economentality: how the future entered government. Critical Inquiry 40(4):579-507. DOI: https://doi.org/10.1086/676417.

Mosse, D. 2005. Cultivating development: an ethnography of aid policy and practice. London: Pluto Press.

Nixon, R. 2011. Slow violence and the environmentalism of the poor. Cambridge, Massachusetts and London: Harvard University Press.

Norte Energia. 2011. Projeto básico ambiental Usina Hidrelétrica Belo Monte (PBA). Brasília: Leme Engenharia Ltda.; CENEC Worley Parsons. 
Norte Energia. 2012a. Estudos complementares do Rio Bacajá. Brasília: Leme Engenharia Ltda.

Norte Energia. 2012b. Nota técnica sobre os Estudos Complementares do Rio Bacajá. Brasília: Leme Engenharia Ltda.

Pignarre, P., e I. Stengers. 2011. Capitalist sorcery: breaking the spell. London: Palgrave Macmillan Stengers.

Ribeiro, G. L. 1988. Empresas transnacionais: um grande projeto por dentro. Tradução Marcos Bagno. São Paulo: Editora Marco Zero e ANPOCS.

Sousa Lima, A. C., e J. P. M. Castro. 2015. Notas para uma abordagem antropológica da(s) política(s) pública(s). Revista Anthropológicas 26(2):17-54.
Stengers, I. 2005. Introductory notes on an ecology of practices. Cultural Studies Review 11(1):183-196. DOI: https://doi.org/10.5130/csr.v11i1.3459.

Stengers, I. 2007. Reativar o animismo. Tradução Jamille Pinheiro Dias. Belo Horizonte: Chão de Feira. (Caderno de Leituras n. 62).

Strathern, M. 2015. Os limites da autoantropologia, in O efeito etnográfico e outros ensaios, pp. 133-157. São Paulo: Cosac Naify.

Zhouri, A., e R. Oliveira. 2013. Conflitos entre desenvolvimento e meio ambiente no Brasil: desafios para a antropologia e os antropólogos, in Desafios da Antropologia brasileira. Organizado por B. Feldman-Bianco, pp. 75108. Brasília: ABA. 
ANEXO 1 - Mapa da dinâmica de ocupação no entorno da bacia hidrográfica do rio Bacajá, das Terras Indígenas e das Unidades de Conservação. Fonte: Norte Energia (2012a).

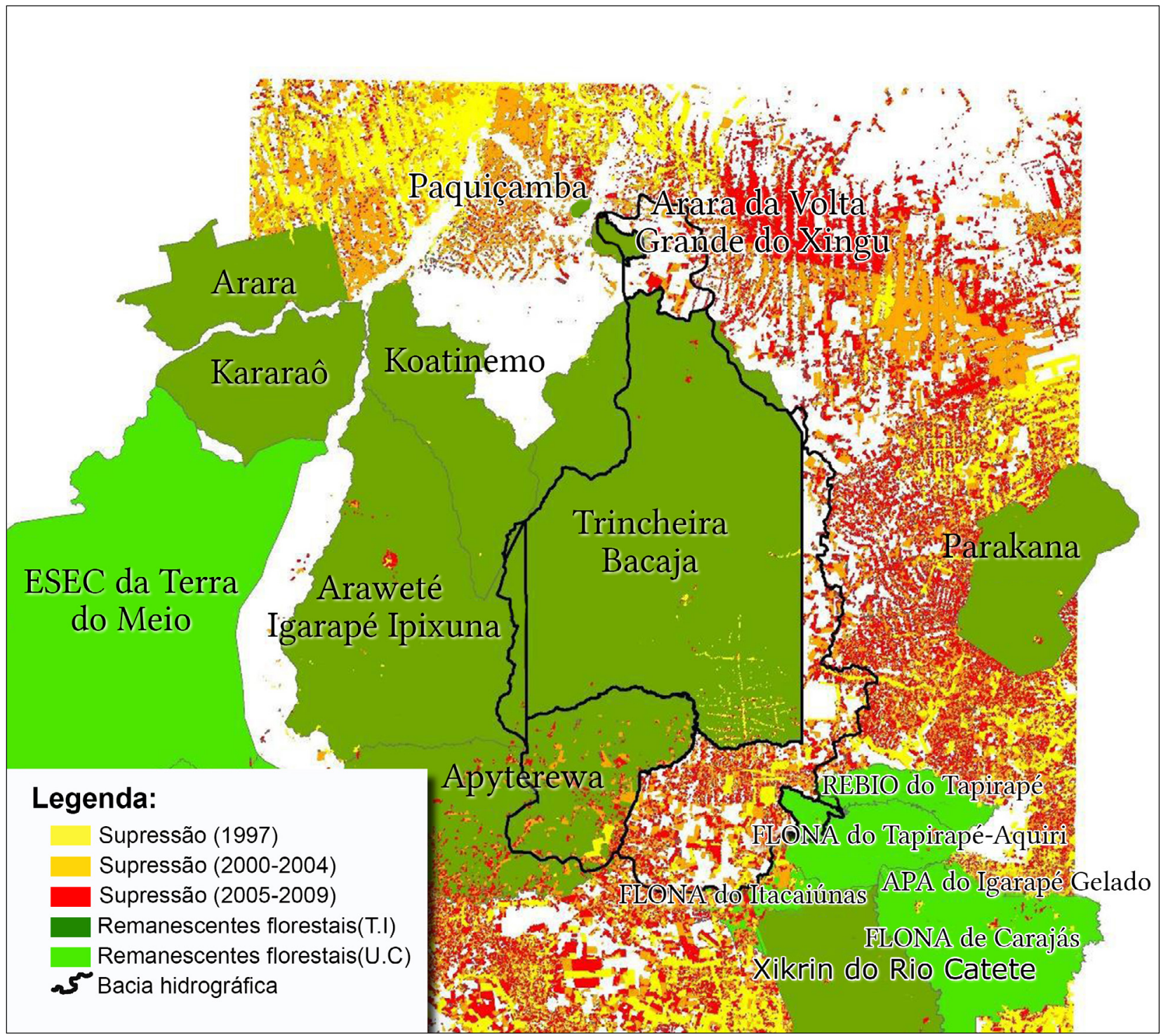

